\title{
Debt Levels, Debt Composition, and Sovereign Spreads in Emerging and Advanced Economies
}

Salvatore Dell'Erba, Ricardo Hausmann, Ugo Panizza

CID Working Paper No. 263

August 2013

(C) Copyright 2013 Dell'Erba, Salvatore; Hausmann, Ricardo;

Panizza, Ugo, and the President and Fellows of Harvard College
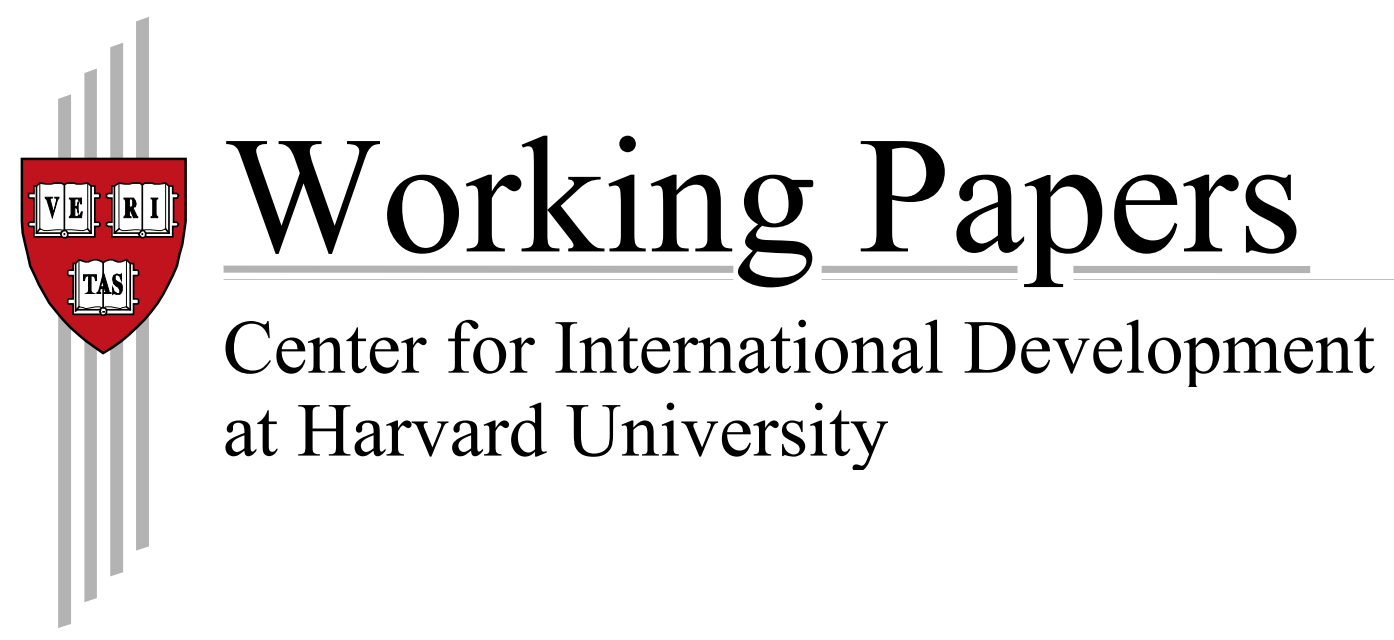


\title{
Debt Levels, Debt Composition, and Sovereign Spreads in Emerging and Advanced Economies
}

\author{
Salvatore Dell'Erba \\ Ricardo Hausmann \\ Ugo Panizza*
}

\begin{abstract}
This paper studies the relationship between sovereign spreads and the interaction between debt composition and debt levels in advanced and emerging market countries. It finds that in emerging market countries there is a significant correlation between spreads and debt levels. This correlation, however, is not statistically significant in countries where most public debt is denominated in local currency. In advanced economies, the magnitude of the correlation between debt levels and spreads is about one fifth of the corresponding correlation for emerging market economies. In Eurozone countries, however, the correlation between spreads and debt ratios is similar to that of emerging market countries. The paper also shows that the financial crisis amplified the relationship between spreads and debt levels within the Eurozone but had no effect on the relationship between spreads and debt in standalone countries. Finally, the paper shows that the relationship between debt levels and spreads is amplified by the presence of large net foreign liabilities. This amplifying effect of net foreign liabilities is larger in the Eurozone than in standalone advanced economies. The paper concludes that debt composition matters and corroborates the original sin hypothesis that, rather than being a mere reflection of institutional weaknesses, the presence of foreign currency debt increases financial fragility and leads to suboptimal macroeconomic policies.
\end{abstract}

Keywords: Spreads, Public debt, Original Sin, Euro

JEL Codes: H63, F33

\footnotetext{
"Dell'Erba is at the Graduate Institute, Geneva (salvatore.dellerba@graduateinstitute.ch), Hausmann at the Kennedy School of Harvard University and director of Harvard's Center for International Development (ricardo_hausmann@harvard.edu), Panizza is at the Graduate Institute, Geneva (ugo.panizza@graduateinstitute.ch). We thank without implication Chris Bowdler and Rui Esteves for helpful comments and suggestions.
} 
This paper examines the relationship between sovereign spreads and the interaction between debt composition and debt levels in advanced and emerging market economies. It shows that debt composition matters as it amplifies the effect of debt levels on sovereign spreads.

We find that in emerging market countries there is a significant correlation between spreads and debt levels. This correlation, however, is not statistically significant in countries where most public debt is denominated in local currency. The correlation between debt levels and spreads is instead high and statistically significant in countries with a large share of foreign currency debt.

In advanced economies, we also find that spreads are significantly correlated with debt ratios, but the magnitude of this correlation is about one fifth of that found in emerging market economies. When we split the advanced economies sample into Eurozone and non-Eurozone countries, however, we find that in the former there is a close relationship between spreads and debt ratios, with elasticities which are similar to what we found in emerging market countries. Elasticities are instead much lower (by a factor of seven) in advanced economies with their own currency. We also find that the financial crisis amplified the relationship between spreads and debt levels within the Eurozone but had no effect on the relationship between spreads and debt in standalone countries. Finally, we show that the relationship between debt levels and spreads is amplified by the presence of large net foreign liabilities, but that the amplifying effect of net foreign liabilities is larger in the Eurozone with respect to standalone advanced economies.

Our results suggest that debt composition matters for sovereign spreads and support Corsetti (2010) and De Grauwe's (2011) hypothesis that countries that join a monetary union face problems that are similar to those of emerging market countries that borrow in foreign currency. In fact, the introduction of the euro is an ideal natural experiment for testing the original sin hypothesis that debt composition has a causal effect on economic outcomes (Hausmann, 1998, Eichengreen and Hausmann, 1999, Eichengreen, Hausmann, and Panizza, 2005a,b, 2007, Hausmann and Panizza, 2003). Our results provide strong evidence that, rather than being a mere reflection of institutional weaknesses, the presence foreign currency debt increases financial fragility and leads to suboptimal macroeconomic policies. 
Our results also corroborates Gros (this volume), Muellbauer (this volume), and Whelan's (this volume) findings that financial fragility is amplified by the presence of large net foreign liabilities and that the global financial crisis tightened the relationship between spreads and fiscal fundamentals in Eurozone countries.

The rest of the paper is organized as follows. Section 2 reviews the literature on the economic effects of public debt by focusing on both debt levels and debt composition. Section 3 studies the relationship between sovereign spreads and debt levels in emerging and advanced economies and shows that Eurozone countries are closer to emerging market economies than to other advanced economies. Section 4 looks at the interaction between debt levels and debt composition in emerging market countries and shows that the presence of foreign currency debt is a key determinant of emerging market spreads. Section 5 looks at the role of net foreign wealth in advanced economies and finds that public debt is particularly problematic in Eurozone countries with large net foreign liabilities. Section 6 concludes.

\section{$2 \quad$ Literature Review}

This section provides a quick review of the empirical literature on the relationship between debt and economic outcomes in emerging and advanced economies. Broadly speaking, this literature can be divided into three, sometimes overlapping, strands: (i) papers that study the relationship between public debt and economic growth; (ii) papers that analyze the relationship between public debt and borrowing costs; and (iii) papers that focus on the role of debt composition.

The papers discussed in this section use different definitions of debt. Specifically, some papers focus on public and private external debt. Others, instead, concentrate on either external public debt or total public debt. The difference between these alternative measures of debt is not as clear-cut as one may think. At times of crisis, private debts are often transferred to the public sector, while public domestic debts can be purchased by the central bank. Moreover, external debt is hard to measure, and there are several practical and conceptual challenges involved in the measurement of total public debt. We discuss some of these issues in Appendix $A$.

\section{Debt and growth}


There are three main channels through which high levels of public or external debt can hamper economic growth: (i) lower investment, if investors think that the proceeds of any new project will be taxed away to service the debt (Krugman, 1988, Sachs, 1989); (ii) policy uncertainty that create incentives to substitute high-return long-term projects with low return short-term investment (Fosu, 1996, Serven, 1997); and (iii) high interest rates that crowd out private investment.

On the empirical side, early work by Green and Villanueva (1991) found that debt levels are negatively correlated with investment in developing countries, but Savvides (1992) found no significant correlation between debt and growth. Cohen (1993) found no significant correlation between debt levels and investment in a sample of 81 developing countries for the period 196587 , but showed that debt was negatively correlated with growth in a sub-sample of Latin American countries.

In a panel of approximately 100 developing countries, Pattillo, Poirson, and Ricci (2011) found a non-linear relationship between the net present value of external debt and economic growth. Their results suggest that the marginal effect of debt becomes negative when the net present value of debt reaches 20 percent of GDP. ${ }^{1}$ Cordella, Ricci, and Ruiz-Arranz (2010), instead, find a negative relationship between external public debt and growth in developing countries with intermediate levels of debt, but no significant relationship between debt and growth in developing countries with very low or very high levels of debt. They also find that in countries with bad policies debt may not matter at all. Presbitero (2012) uses total public debt and finds no significant relationship between public debt and growth in developing countries with bad policies and institutions.

The literature that focuses on the relationship between public debt and economic growth in advanced economies is more recent. A good starting point for discussing this literature is Reinhart and Rogoff's (2010) finding that high levels of debt are negatively correlated with economic growth, but that there is no link between debt and growth when public debt is below 90 percent of GDP. Reinhart and Rogoff's (2010) influential paper sparked a large literature aimed at assessing whether its findings were robust to allowing for non-arbitrary debt brackets, to controlling for other variables, and to instrumenting public debt to assess its causal effect on

\footnotetext{
${ }^{1}$ Pattillo, Poirson, and Ricci (2003) interact debt ratios with a measure of country policies and find that for highly indebted countries the negative impact of debt on growth is stronger for countries with bad policies.
} 
economic growth. ${ }^{2}$ Panizza and Presbitero (2013) provide a detailed survey of this literature and conclude that, while there is evidence that public debt is negatively correlated with economic growth, there is no study that can make a strong case for a causal relationship going from debt to growth. ${ }^{3}$ They also show that the presence of debt thresholds and, more generally, of a nonmonotonic relationship between debt and growth is not robust to small changes in data coverage and empirical techniques. Panizza and Presbitero (2013) conclude that an assessment of the complex relationship between debt and growth requires more research and that this research should focus on causality and cross-country heterogeneity.

\section{Debt and Spreads}

The Brady exchanges of the early 1990s created an active secondary market for emerging market sovereign bonds and sparked a large literature aimed at estimating the determinants of emerging market spreads (for a recent survey, see Belhocine and Dell'Erba, 2013). While there is no consensus on what is the best empirical model for assessing the determinants of emerging market sovereign bond spreads, there is broad agreement that both local and global factors are important. Several studies have thus found that spreads are negatively associated with international reserves coverage and trade openness and positively associated with current account deficits, inflation, and external debt. External factors such as risk appetite, global liquidity, and contagion are also important determinants of sovereign spreads in emerging markets (González Rozada and Levy Yeyati, 2008, find that global factors explain about one third of the volatility of emerging market spreads). A recent paper by Aizenman, Jinjarak, and Park (2013) finds that the most important determinants of emerging market spreads in the precrisis periods (2004-07) were trade openness and state fragility. During the crisis period (200809 ), instead, spreads were closely associated with inflation and the external debt ratio, and in the post-crisis periods (2010-12) the main drivers of spreads were public debt and inflation.

An alternative view suggests that certain countries (mostly frontier and emerging markets) have a weak institutional set up which makes them intolerant to debt. In support of this view, Reinhart, Rogoff and Savastano (2003) show that credit ratings (which, in turn, are closely correlated with

\footnotetext{
${ }^{2}$ The discussion on the relationship between debt and growth in advanced economies become particularly animated after the publication of a paper by Herndon, Ash, and Pollin (2013) who pointed out to some problems with Reinhart and Rogoff's data and methodology.

${ }^{3}$ This is also an issue for the studies that focus on developing and emerging market countries. None of these studies use external instruments. They all identify the relationship between debt and growth by instrumenting debt with its past values.
} 
sovereign spreads) are tightly correlated with debt levels only in this subgroup of "debt intolerant" countries.

Rather than focusing on spreads, studies that cover advanced economies have often concentrated on long term yields that combine default risk with inflationary expectations. ${ }^{4} \mathrm{~A}$ recent study by Greenlaw, Hamilton, Hooper, and Mishkin (2013) focuses on 20 advanced economies for the period $2000-10$ and finds that a 10 percentage point increase in the debt-toGDP ratio is associated with a 45 basis point increase in sovereign yields. Using different samples and methodologies, Alper and Forni (2011) find that a ten percentage point increase in the debt-to-GDP ratio is associated with an increase in long-term yields that ranges between 10 and 70 basis points. Ichiue and Shimizu (2012) find that a ten percentage point increase in public debt is associate with a 13-16 basis point increase in long-term yields.

Papers that find a positive correlation between the level of public debt and long-term yields do not control for the fact that about half of the countries included in their samples belong to the Eurozone. According to Corsetti (2010) and De Grauwe (2011), members of a monetary union are similar to emerging market countries that suffer from Original Sin (Eichengreen and Hausmann, 1999, and Hausmann, 1998). As members of the Eurozone do not have a domestic lender of last resort that can rule out self-fulfilling liquidity crises, their government bond markets are more fragile and more susceptible to self-fulfilling liquidity crises than those of standalone countries. De Grauwe and Ji (2013) test this hypothesis and find that the level of public debt is significantly correlated with long-term sovereign spreads in the Eurozone but that debt ratios have no statistically significant impact on sovereign spreads in standalone countries. In this paper, we provide further evidence in this direction.

The role of debt composition

The wave of financial crises that hit several emerging market countries in the second half of the 1990s led to an intense debate on the role of debt composition and currency denomination. While there was an agreement on the fact that all crisis countries were characterized by the presence of large foreign currency liabilities, some economists suggested that the currency denomination of the debt was a mere reflection of bad domestic policies and institutions, and

\footnotetext{
${ }^{4}$ There are a few exceptions to this trend. For instance, Favero et al. (1997) and Codogno et al. (2003) study spreads in advanced economimes.
} 
that these bad policies and institutions were the true cause of the crises (Reinhart, Rogoff, and Savastano, 2003, Goldstein and Turner, 2004).

Other economists, instead, argued that debt denomination has a causal effect on economic outcomes. The original sin hypothesis, first articulated by Hausmann (1998) and Eichengreen and Hausmann (1999), describe a situation in which "the domestic currency is not used to borrow abroad or to borrow long-term even domestically" (p. 330). In follow up work, Eichengreen, Hausmann, and Panizza (2005a,b, 2007) and Hausmann and Panizza (2003) showed that the international component of original sin is a widespread and persistent phenomenon which is not a mere consequence of bad policies or institutions. They also showed that original sin is associated with low credit ratings, a limited ability to conduct an independent monetary policy, and high macroeconomic volatility. Hausmann and Panizza (2012) show that since the beginning of the new millennium several developing countries have been making greater use of domestic bond markets, with a corresponding decline in gross and net foreign debt-to-GDP ratios. They also show that emerging market countries with lower levels of foreign currency debt are better able to conduct countercyclical macroeconomic policies.

The importance of debt composition is also confirmed by Du and Schreger (2013) who study 10 emerging market countries over 2005-11 and show that local currency sovereign spreads are much smaller than the corresponding foreign currency spreads. In their sample, local currency spreads have an average of 128 basis points and foreign currency spreads have an average of 195 basis points. They also find that foreign currency spread increased much more than local currency spreads during the peak of the global financial crisis (230 basis points versus 90 basis points). Du and Schreger (2013) also find that local currency spreads are less correlated across countries than foreign currency spreads and that foreign currency spreads are more correlated with global risk factors than local currency spreads.

If we exclude the case of the Eurozone discussed above, advanced economies do not issue much foreign currency public debt (Panizza and Presbitero, 2012). Therefore, there is no welldeveloped literature on the effect of foreign currency public debt in advanced economies. There is, however, some work that analyzes the problems associated with external borrowing by advanced economies. For instance, Gros (this volume) argues that public debt owed to foreigners is much riskier than domestic public debt. In this paper, we contribute to this literature 
by analyzing how the presence of external debt affects the relationship between debt and spreads in advanced and emerging market economies.

\section{Debt and spreads in emerging and advanced economies}

This section studies the correlation between debt levels and sovereign spreads in different types of countries during tranquil and crisis periods. ${ }^{5}$

We assess the elasticity of credit risk (measured by sovereign spreads) to the debt-to-GDP ratio by estimating the following equation separately for advanced and developing economies:

$$
S_{i, t}=\alpha_{i}+\tau_{t}+\gamma D E B T_{i, t-1}+\varepsilon_{i, t}
$$

In Equation (1), $S_{i, t}$ measures the sovereign spread (in basis points) in country $i$ and period $t, \alpha_{i}$ and $\tau_{t}$ are country and period fixed effects, $D E B T_{i, t}$ is the gross public debt-to-GDP ratio in country $i$, period $t$, and $\varepsilon_{i, t}$ is the error term.

In Equation, (1) all global time-variant determinants of spreads are captured by the time fixed effects and all country-specific time-invariant determinants of spreads are captured by the country-fixed effects. However, Equation (1) deviates from the literature described in Section 2 because it does not control for country-specific time-variant determinants of sovereign spreads. We decided not to include additional control variables because we want to highlight the role of debt and its interaction with country characteristics. Adding additional controls would have led to multicollinearity problems and greatly complicated the interpretation of the interactive effects that we discuss below. We are aware that our parsimonious specification may be subject to an omitted variable bias, but we are confident that our two-way fixed effects model can capture a large share of unobserved heterogeneity. We are also comforted by the fact that our results are in line with those of De Grauwe and Ji (2013) who use a different specification and control for a large set of covariates.

\footnotetext{
${ }^{5}$ While the focus on sovereign spreads is standard in papers that concentrate on emerging market countries, papers that study the determinants of borrowing costs in advanced economies tend to focus on long-term yields. We decided to focus on sovereign spreads in order to have a pure measure of credit risk (long-term yields also capture inflationary and depreciation expectations) which is comparable across advanced and emerging economies.
} 
After having established the basic correlation between debt levels and spreads, we check whether the recent financial crisis has affected elasticity to fundamentals by estimating the following equation:

$$
S_{i, t}=\alpha_{i}+\tau_{t}+D E B T_{i, t-1}\left\{\gamma_{1}+\gamma_{2}(C R I S I S)\right\}+\varepsilon_{i, t}
$$

CRISIS is a dummy variable that takes a value of one for the $2008 \mathrm{H} 2-2012$ period and zero for all other periods. In this set up, $\gamma_{1}$ measures the elasticity of spreads to the debt-to-GDP ratio in the pre-crisis period, and $\gamma_{2}$ measures the difference between the elasticity of spreads to the debt-to-GDP ratio before and after the global financial crisis $\left(\gamma_{1}+\gamma_{2}\right.$ measures the elasticity after the crisis).

For the advanced economies, we also test whether the elasticity of spreads to the debt ratio is different from Eurozone countries. Specifically, we estimate the following equation.

$$
S_{i, t}=\alpha_{i}+\tau_{t}+D E B T_{i, t-1}\left\{\beta_{1}+\beta_{2}\left(E U R O_{i, t}\right)\right\}+\theta E U R O_{i, t}+\varepsilon_{i, t}
$$

EURO is a dummy variable that takes a value of one for Eurozone countries and zero for the other advanced economies (EURO is time-variant and always takes a value of zero before 1999). In this set up, $\beta_{1}$ measures the elasticity of spreads to debt outside the Eurozone, and $\beta_{2}$ measures the difference between elasticities to debt within and outside the Eurozone $\left(\beta_{1}+\beta_{2}\right.$ is the elasticity within the Eurozone). Notice that the presence of country and period fixed effects make Equation (3) equivalent to a differences-in-differences estimations of how the introduction of the euro affected the relationship between spreads and the debt-to-GDP ratio in advanced economies.

Finally, we allow for different elasticities to debt ratios in Eurozone and non-Eurozone countries during crisis and tranquil periods. Formally, we estimate the following equation:

$$
S_{i, t}=\alpha_{i}+\tau_{t}+D E B T_{i, t-1}\left[\delta_{1}+\delta_{2} C R I S I S+E U R O_{i, t}\left(\delta_{3}+\delta_{4} C R I S I S\right)\right]+\theta E U R O_{i, t}+\varepsilon_{i, t}
$$

In this setting, $\delta_{1}$ measures how spreads react to the debt-to-GDP ratio in non-Eurozone countries during tranquil periods and $\delta_{1}+\delta_{2}$ measures elasticity to the debt ratio in non- 
Eurozone countries during the global financial crisis; $\delta_{1}+\delta_{3}$ and $\delta_{1}+\delta_{2}+\delta_{3}+\delta_{4}$ measure the corresponding elasticities for Eurozone countries.

\subsection{Data}

We estimate equations 1-4 using biannual data for a sample of 26 emerging markets (EM) countries and 15 advanced economies (AE) using an unbalanced panel over the period 1993H12012H1. The sample excludes the United States and Germany (which are used as benchmark to calculate the spreads) and all country-periods during which a country was in default or was approaching a sovereign default (Table A1 in the Appendix lists all the country-years included in the analysis). In our benchmark regressions, we also exclude Greece and Portugal because they tend to be outliers in the spread dimensions. All our results are robust to including Greece and Portugal (in fact, including these two countries in our sample strengthens our results).

For emerging market countries, we measure country risk with the JP Morgan EMBI Spreads. ${ }^{6}$ For Eurozone countries, we use German government Bunds as a benchmark and for advanced economies that never adopted the euro we use US Treasury bonds as benchmark. For Eurozone countries after the creation of the euro, we obtain spreads by subtracting German yields from country-specific yields. For countries outside the Eurozone and for Eurozone countries in years prior to 1999, we compute a measure of pure credit risk by adjusting yields differentials with exchange rate risk. Specifically, we follow Codogno et al. (2003) and define sovereign spreads as:

$$
s_{i t}=\left(y_{i t}-y_{b t}\right)-\left(i r_{i t}-i r_{b t}\right)
$$

Where $y_{i t}$ is the yield of country $i, y_{b t}$ is the yield of the benchmark country (Germany for EMU countries and the US for the other advanced economies), $i r_{i t}$ is the interest rate swap of country $i$, and $i r_{b t}$ is the interest rate swap of the benchmark country. ${ }^{7}$

To address endogeneity of fundamentals to sovereign risk, we follow Laubach (2009) and use forecasts rather than outcomes of macro-fiscal fundamentals. We collect forecasts from previous

\footnotetext{
${ }^{6} \mathrm{EMBI}$ spreads are averages of the spread (with respect to US Treasury) on foreign currency denominated debt weighted by the outstanding share of debt by relevant maturity.

${ }^{7}$ Interest rate swaps are contracts that allow to exchange fixed for floating interest payments in different currencies.
} 
vintages of the April and November issue of the IMF World Economic Outlook (WEO), available since 1993. We regress the spreads observed in the month after the release of the forecast over the set of chosen macro and fiscal variables published in the previous month's WEO, which is equivalent to imposing the (mild) assumption that markets align their expectations over a country' s macro and fiscal fundamentals with those embodied into the IMF forecasts.

While our analysis focuses on the general government gross public debt-to-GDP ratio, we also explore the role of general government gross public debt-to-government revenues ratio and of a country-period specific composite index equal to the first principal component of the debt-toGDP, deficit-to-GDP, and current account-to-GDP ratios. In building this index, we compute the first principal component separately for developing and advanced economies and then rescale the index to range between 0 and 1 in both subsamples. A higher value of the aggregate index is associated with worse fundamentals.

Table A2 in the Appendix shows the correlation between the index of fundamentals and its components. In developing countries, the index is highly correlated with public debt and the current account deficit (the correlation coefficients are about 0.7 and 0.8 , respectively). The correlation with the primary budget deficit is instead negative. In advanced economies, instead, the index is highly correlated with the primary deficit $(0.92)$, but also positively correlated with debt and the current account deficit.

\subsection{Summary statistics}

In the emerging market countries included in our sample, average spreads were 342 basis points in the pre-crisis period and 398 basis points in the crisis period (Table 1). The overall average was 360 basis points. Average debt-to-GDP ratios were lower during the crisis period (39 versus 43 percent of GDP, the debt-to-revenues ratio went from 175 percent to 157 percent), However, the budget deficit and the current account deteriorated during the crisis. As a consequence, the overall index of fundamentals remained essentially the same in the two subperiods.

In advanced economies, average spreads were 11 basis points in the pre-crisis period and increased to 66 basis points during the crisis period. The overall average was 23 basis points, with spreads ranging between -105 and 664 basis points (these numbers do not include Greece 
and Portugal, where spreads peaked at 3100 and 1100 basis points, respectively).

Fundamentals deteriorated during the crisis, with average debt-to-GDP ratio going from 70 to 83 percent of GDP (the debt to revenues ratio went from 164 percent to 209 percent). Over the same period, the average index of (bad) fundamentals increased from 0.62 to 0.72 .

Among advanced economies, pre-crisis spreads were lower in the Eurozone (7 basis points) than outside the Eurozone (15 basis points), even though the Eurozone had worse fundamentals. During the crisis, fundamentals deteriorated in both Eurozone and non-Eurozone advanced economies, with the index of (bad) fundamentals increasing by approximately 0.1 in both groups of countries. However, average spreads moved in opposite directions. They became negative in non-Eurozone countries and climbed to 138 basis points inside the Eurozone. The crisis also led to a tenfold increase of the variance of spreads within the Eurozone.

\subsection{Regression results}

We start by estimating Equation (1) for the subsample of emerging market countries (Column 1 of Table 2). ${ }^{8}$ We find that the debt to-GDP ratio is significantly correlated with spreads and that the point estimate suggests that a ten percentage point increase in the debt-to-GDP ratio is associated with a 45 basis points increase in sovereign spreads. Alternatively, a one-standard deviation increase in the debt-to-GDP ratio (21 percent of GDP) is associated with a 100 basis point increase in sovereign spreads. We also find that the global financial crisis increased the elasticity of spreads to the debt ratio, but that the coefficient of the interactive effect is not statistically significant (column 2 of Table 2).

Given that debt is serviced with government revenues and not GDP, we also estimate Equations (1) and (2) using public debt as a share of revenues. Also in this case, we find a significant correlation between debt and spreads which does not seem to be significantly affected by the financial crisis (columns 3 and 4 of Table 2). Finally, we estimate the relationship between spreads and the composite index of fundamentals. Again, we find a statistically significant relationship between fundamentals and spreads (the point estimates suggest that a one-

\footnotetext{
${ }^{8}$ Note that in emerging economies, we use spreads on foreign currency, which is mostly external, debt but we compute debt ratios using total public debt (a measure that includes a large and growing share of domestic debt denominated in domestic currency). We return to this issue in Section 4 below.
} 
standard deviation increase in the index is associated with a 55 basis point increase in the spread, column 5 of Table 2). In this case, we find that the financial crisis interactive effect has a negative coefficient, but the coefficient is not statistically significant.

Next, we estimate Equation (1) for our sample of advanced economies. We find a statistically significant relationship between public debt and sovereign spreads (column 1, Table 3), but with a coefficient which is much smaller than what we found in emerging markets. In the advanced economies, a 10 percentage point increase in public debt is associated with a 6 basis point increase in sovereign spreads. Alternatively, a one-standard deviation increase in the debt-toGDP ratio is associated with a 20 basis point increase in spreads, about one fifth of what we found in emerging market countries. Again, we find that the global financial crisis had no statistically significant effect on the elasticity of spreads to public debt (column 2, Table 3).

The first two columns of Tables 2 and 3 show that the impact of debt ratios on spreads is 5 times larger in emerging market countries than in advanced economies. This finding is consistent with both the original sin (Eichengreen et al., 2005a) and the debt intolerance (Reinhart et al., 2003) hypotheses. According to the original sin hypothesis, the difference between advanced and developing economies is that the former tend to borrow in domestic currency and the latter tend to borrow in foreign currency. According to the debt intolerance hypothesis, the higher elasticity of emerging markets is due to the fact that these countries tend to have weak institutions and low tolerance to debt.

We can use the creation of the euro as a natural experiment to discriminate between these two hypotheses. Countries that join a monetary union lose their domestic lender of last resort and become similar to countries that borrow in foreign currency (Corsetti, 2010, and De Grauwe, 2011). At the same time, it would be hard to claim that the creation of the euro worsened the institutions of the member countries. If we were to find that the creation of the euro made formerly tolerant countries debt intolerant, it must have been because of the change in debt structure.

When we test this hypothesis by estimating the differences-in-differences specification of Equation (3), we find a small (and marginally significant) elasticity of spreads to debt ratios for non-Eurozone countries and a much larger and highly significant elasticity for countries in the Eurozone. Specifically, the point estimates suggest that a ten percentage point increase in the 
debt-to-GDP ratio is associated with a 3 basis point increase in sovereign spreads outside the Eurozone and a 25 basis point increase in spreads within the Eurozone (column 3, Table 3). A one standard deviation increase of the debt-to-GDP ratio in the Eurozone is associated with an 80 basis point increase in spreads, nearly the same elasticity that we found in emerging market countries. $^{9}$

We can formally test whether the relationship between spreads and debt ratios is similar in Eurozone advanced economies and emerging market economies by estimating the following equation for the joint sample of emerging and advanced economies:

$S_{i, t}=\alpha_{i}+\tau_{t}+D E B T_{i, t-1}\left\{\beta_{1}+\beta_{2}\left(E U R O_{i, t}\right)+\beta_{3} A E_{i} \times\left(1-E U R O_{i, t}\right)\right\}+\theta E U R O_{i, t}+\varepsilon_{i, t}$

In this set up, $\beta_{1}$ measures the elasticity of spreads to debt ratio in emerging market countries, $\beta_{2}$ measures the difference in elasticity between emerging market economies and the countries that belong to the Eurozone, and $\beta_{3}$ measures the difference in elasticity between emerging market economies and standalone advanced economies. We find that the debt ratio has a large and statistically significant effect on spreads in emerging economies $\left(\beta_{1}=3.61\right.$; $t$-stat $\left.=4.49\right)$, that the elasticity to spreads in Eurozone countries is not significantly different from that of emerging market countries $\left(\beta_{2}=-299\right.$; $\mathrm{t}$-stat=3.58), and that the elasticity of spreads to debt is significantly lower in standalone advanced economies $\left(\beta_{3}=-0.28\right.$; $\mathrm{t}$-stat=0.29).

While our regressions exclude Greece and Portugal (if we include Greece and Portugal in our sample we obtain stronger results, Column 4 of Table 3), our results may be driven by extreme observations in other countries in the periphery of the Eurozone. As there is no standard way to deal with such outliers, we estimate the correlation between the debt-to-GDP ratio and spreads by running country-by-country regressions for the post 1998 period.

\footnotetext{
${ }^{9}$ The main effect of the euro dummy is negative and statistically significant. While spreads in the Eurozone are more sensitive to debt ratios, other things equal Eurozone countries tend to have lower spreads. De Grauwe and Ji (2013) test a model similar to that of Equation (4) and find results which are similar to ours. There are three main differences between their tests and ours: (i) they use a different specification with a large set of covariates and allow for non-liner effects of public debt; (ii) they use a larger sample of advanced economies and quarterly data starting in 2000 instead of annual data starting in the mid-1990s; given that their data start after the creation of the euro, De Grauwe and Ji (2013) cannot conduct a difference in difference analysis; (iii) they control for exchange rate risk but use yields instead of spreads.
} 
These regressions are based on small samples of 27 observations, but they do not suffer from possible aggregation problems which may affect the panel regressions of Table 3 . The results are striking and indicate that the results of Table 3 are unlikely to be driven by outliers in the Eurozone periphery. In our sample of 6 non-Eurozone countries, there are 2 countries with a

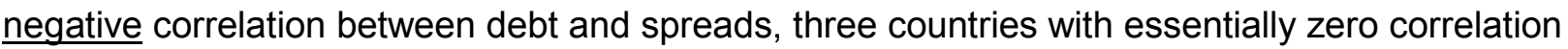
between debt and spreads, and one country (Sweden) with a positive and statistically significant correlation between debt and spreads (Table 4). In the subsample of 9 Eurozone countries, we always find a positive correlation between debt and spreads. For 7 of these countries, the correlation is statistically significant. While the correlation between debt and spreads tend to be higher in crisis countries (Greece, Italy, Portugal and Spain), the correlation is also statistically significant in most core countries. Strong fundamentals do not shield countries from vulnerabilities associated with the presence of foreign currency debt.

The summary statistics of Table 1 show that the global financial crisis may have had a different effect on the relationship between spreads and debt in Eurozone and non-Eurozone countries. Before the crisis, Eurozone countries had worse fundamentals and lower spreads than nonEurozone countries. The crisis led to a similar deterioration of fundamentals inside and outside the Eurozone, but average spreads increased inside the Eurozone and decreased outside the Eurozone. This is consistent with the findings of Muellbauer (this issue) and Whelan (this issue) that the financial crisis increased the correlation between debt ratios and spreads within the Eurozone.

Equation (4) allows for a differential reaction to the global financial crisis in Eurozone and nonEurozone countries and shows that the crisis did not increase the correlation between spreads and debt in non-Eurozone advanced economies (if anything, this elasticity decreased, but the effect is not statistically significant; Column 5, Table 3). In Eurozone countries, instead, the correlation between debt and spreads more than doubled after the beginning of the global financial crisis. The point estimates suggests that a 10 basis point increase in the debt-to-GDP ratio increases spreads by 5 basis points in non-Eurozone countries during tranquil periods, 3 basis point in non-Eurozone countries in crisis periods, 14 basis points in Eurozone countries during tranquil periods, and 30 basis points in Eurozone countries during crisis periods (Figure 1)..$^{10}$

\footnotetext{
${ }^{10}$ These elasticities are based on the point estimates of column 5 (column 6, which includes Greece and Portugal yields even higher elasticities for Eurozone countries).
} 
To check whether our results are driven by outliers, we re-estimate our model using a robust regression procedure that puts less weight on outliers (Stata's rreg routine, the regression with interactions are too demanding for country-by-country regressions). Controlling for outliers yields lower elasticities, but we still find that in the Eurozone the elasticity of spreads to debt ratios increased significantly after the beginning of the global financial crisis (column 7 of Table 3 , the coefficients are plotted by the light bars in Figure 1). The last two columns of Table 3 also show that the robust regression routine yields similar results in the subsamples of advanced economies that include and do not include Greece and Portugal.

Even though, the index of fundamentals is not perfectly correlated with the debt-to-GDP ratio, we find that the correlation between fundamentals and spreads is similar to what we found when we looked at the correlation between debt ratios and spreads. In particular, the elasticity of spreads to fundamentals is higher in Eurozone countries, especially after the crisis (Table 5). This is also confirmed in the country-by-country regressions of the left panel of Table $4 .^{11}$

The results of this section can be summarized as follows: (i) spreads react to debt ratios in both advanced and emerging market economies, but the elasticity of spreads to debt ratios is about 5 times larger in emerging market countries; (ii) on average, the global financial crisis had no statistically significant effect on the relationship between debt ratios and spreads in emerging market and advanced economies; (iii) when we split the advanced economies sample into Eurozone and non-Eurozone countries, we find that in Eurozone countries there is a tight relationship between spreads and debt ratios, with elasticities that close to what we found in emerging market countries. Elasticities are instead much lower (by a factor of seven) in nonEurozone advanced economies; and (iv) the financial crisis amplified the relationship between debt and spreads within the Eurozone but had no effect on the relationship between spreads and debt in standalone countries.

We suspect that these results are due to differences in debt composition and to the fact that the creation of the euro has led to a situation in which countries in the Eurozone now suffer from

\footnotetext{
${ }^{11}$ We also find similar results if we use the debt-to-revenues ratio. This is not surprising because in advanced economies there is a 93 percent correlation between the debt-to-GDP ratio and the debt-to-revenues ratio (the correlation is much lower in emerging market countries).
} 
original sin (Corsetti, 2010, and De Grauwe, 2011). In the next two sections, we study the role of debt composition.

\section{$4 \quad$ Spreads and Debt Composition in Emerging Markets}

To explore how debt structure affects the relationship between debt and spreads in emerging market countries it would be necessary to have detailed data on the currency and maturity composition of external and domestic public debt. However, data on debt composition is only available for a small subset of countries (Jeanne and Guscina, 2006 and Cowan et al., 2006). Hence, we start with a simple split between domestic and external debt (even measuring external debt is not a straightforward exercise; see Appendix A for details) and check if, conditional on debt levels, countries with a larger share of external debt face higher spreads.

We start by augmenting the model in the first column of Table 1 with a variable that captures the share of external public debt (SH_ED). We find that the debt variable remains significant (with an elasticity which is similar to what we obtained in Table 1), but that the share of external debt also matters for spreads. In particular, we find that a 20 percentage point increase in the share of external debt (this is equivalent to one standard deviation) is associated with a 40 basis points increase in spreads (column 1, Table 6).

Next, we interact the debt-to-GDP ratio with the external debt share to capture how the level of public debt affects spreads for countries with different shares of external debt. We find that the direct effect of debt remains statistically significant, and the point estimates suggest that the correlation between debt levels and spreads increases with the share of external debt. While the interactive term is not statistically significant (Column 2, Table 6), the total effect is significant. The point estimates indicate that in emerging market countries with low levels of external debt there is no statistically significant correlation between public debt and sovereign spreads, but the correlation between debt and spreads is statistically significant in countries in which most public debt is owed to foreigners. For instance, in countries where 80 percent of public debt is external, a ten percentage point increase in the debt-to-GDP ratio is associated with a 50 basis point increase in sovereign spreads (Figure 2, panel a).

While most foreign debt issued by emerging market countries is denominated in foreign currency, some countries are able to issue abroad in domestic currency or are able to swap 
foreign currency obligations with domestic currency debt issued by non-residents. Foreign debt denominated in domestic currency may reduce vulnerabilities because it does not lead to currency mismatches and because it allows the domestic central bank to act as a lender of last resort. In fact, Du and Schreger (2013) show that, in emerging market countries, local currency sovereign spreads are much smaller than the corresponding foreign currency spreads.

To control for the fact that not all external debt of developing countries is denominated in foreign currency and that some foreign currency exposure can be hedged through swaps, we adjust the share of external debt with one of the indexes of original sin developed by Eichengreen, Hausmann, and Panizza (2005a). In particular, we use BIS data on the currency composition of international securities to compute the following index of original sin:

$$
\operatorname{OSIN}_{i, t}=\max \left(1-\frac{\text { Securities issued in currency } i_{t}}{\text { Securities issued by country } i_{t}}, 0\right)
$$

This index accounts for the fact that debt issued by other countries in a country's currency creates an opportunity to hedge currency exposures via the swap market. It also recognizes that this measure can take on negative values (for countries which have more debt issued in their currency than debt issued by residents) and imposes a lower bound to original sin (because a negative value would be meaningless for our purposes as countries cannot hedge more than the debt they have). ${ }^{12}$ Next, we multiply the share of external debt for OSIN, to obtain a measure of the share of public debt which is in foreign currency and cannot be hedged through swaps:

$$
S H_{-} E D O S_{i, t}=S H_{-} E D S_{i, t} \times O S_{i, t}
$$

Column 3 of Table 6 shows that SH_EDOS is significantly correlated with sovereign spreads and column 4 shows that the interactive effect is statistically significant, indicating that the relationship between spreads and the debt-to-GDP ratio is increasing in SH_EDOS. Besides being statistically significant, the point estimate of the interactive effect is much larger than what we found for the share of external debt that does not control for currency composition (compare the first two panels of Figure 2).

\footnotetext{
${ }^{12}$ For a detailed discussion on the recent evolution of OSIN, see Hausmann and Panizza (2011).
} 
In column 5, we run a horserace regression and interact the level of debt with both SH_ED and SH_EDOS. We find that the interaction with SH_EDOS remains statistically significant with a point estimate which is essentially identical to that of column 4. SH-ED, instead, remains insignificant and its point estimate goes from 2.6 to 0.7. Panel c of Figure 2 shows that, once we control for foreign currency debt, the share of external debt has no impact on the relationship between spreads and the debt-to-GDP ratio. The presence of foreign currency debt, instead, leads to a tighter relationship between debt levels and spreads (panel d, Figure 2).

We now check if foreign wealth matters for spreads and for the relationship between spreads and the debt-to-GDP ratio. Column 1 of Table 7 shows that countries with large foreign net wealth (expressed as a share of GDP) tend to pay lower spreads. Column 2 shows that the relationship between debt levels and spreads is decreasing in the level of net foreign wealth. The interactive term is large and precisely estimated, suggesting that there is no statistically significant relationship between debt and sovereign spreads in countries with positive net foreign wealth. In countries which have net foreign liabilities equal to 50 percent of GDP a ten percentage point increase in the debt to GDP ratio is associated with 50 basis point increase in sovereign spreads (Panel a, Figure 3).

When we estimate the model of column 2 also controlling for the interaction between the level of public debt and the share of foreign currency debt (column 3, Table 7), we find that the relationship between debt and spreads is increasing in the share of foreign currency debt (Panel d, Figure 3), with essentially the same slope that we found in the regressions of Table 6 (Panel b, Figure 3). The interaction with net foreign assets remains statistically significant but the slope is now about half of what we found in the model that does not control for the interaction with the foreign currency debt ratio (Panel c of Figure 3). Given that the regressions that include SH_EDOS are based on a much smaller sample with respect to the regressions that only include net foreign assets (370 observations instead of 600), we re-estimated the model of column 2 using the same sample of column 3 and found that the difference in the magnitude of the interactive term is due to the smaller sample and not to differences in the specification.

Taken together, the regressions of Table 6 suggest that what matters is foreign currency debt and not the share of debt owed to foreign creditors. ${ }^{13}$ The regressions of Table 7 , instead,

\footnotetext{
${ }^{13}$ Unfortunately, we do not have data to analyze how the currency composition of domestic debt affects the relationship between spreads and debt level.
} 
indicate that the relationship between spreads and the level of debt is mitigated by the presence of net foreign assets, but that the relationship between foreign currency debt and spreads is robust to controlling for net foreign wealth.

\section{$5 \quad$ Spreads and Debt Composition in Advanced Economies}

We now look at whether debt composition affects the relationship between debt levels and spreads in advanced economies. Unlike emerging market countries, advanced economies have small shares of foreign currency public debt (Panizza and Presbitero, 2012, find that the average currency share in OECD countries ranges from 0 to 9 percent with a cross-country average of 3 percent). Therefore, we focus on the share of external debt (without controlling for currency composition) and on the role of net external wealth. Even the regressions with the share of external debt are problematic because data on debt composition for advanced economies start in 1998 (moreover, until 2001 we have data on debt composition for only two advanced economies).

Column 1 of Table 8 shows that in the subsample of advanced economies for which we have data on the share of external debt there is no significant relationship between sovereign spreads and either debt level and debt composition. When we interact debt levels with debt composition, we find that the correlation between spreads and the debt-to-GDP ratio increases with the share of external debt, but the relationship between spreads and external debt is not statistically significant until external debt reaches 60 percent of total debt (Panel a, Figure 4; a 60 percent external debt share corresponds to one standard deviation above the sample mean).

Column 3 shows that spreads are lower in countries with net foreign assets and column 4 shows that the positive relationship between debt levels and sovereign spreads does not hold for countries with moderate and large net foreign assets. Specifically, the coefficient becomes insignificant for countries with net foreign assets greater than 10 percent of GDP (panel b, Figure 4). In column 5, we interact the debt level with external debt and net foreign assets and find that the coefficients of the interactive effects have the expected positive and negative signs but that the interaction between debt and net foreign assets is not statistically significant and the point estimate is much smaller than what we found in column 4 (this can be seen by comparing panels $b$ and $d$ of Figure 4). In this case, the difference between the estimates of columns 4 and 5 is not 
due to the fact that the latter are based on a smaller sample. If we estimate the model of column 4 using the sample of column 5 , we find results close to those of column 4.

\subsection{The euro as foreign currency debt}

While advanced economies do not have large foreign currency sovereign debt, the introduction of the euro created something akin to a foreign currency because the national central banks of Eurozone countries can no longer act as a lender of last resort or conduct an independent monetary policy (Corsetti, 2010, and De Grauwe, 2011). The regressions of Table 3 already showed that the relationship between sovereign spreads and the level of public debt is tighter in the Eurozone. We now check if, as suggested by Gros (this volume), external debt is particularly dangerous for Eurozone countries.

Column 1 of Table 9 shows that outside the Eurozone there is no significant correlation between spreads and either the debt-to-GDP ratio or the share of external debt. The opposite is instead true inside the Eurozone. In this case, the point estimates suggest that a 10 percentage point increase in public debt is associated with a 33 basis point increase in sovereign spreads and a 10 percentage point increase in the share of foreign debt is associated with a 13 basis point increase in spreads. In column 2, we interact public debt with the share of external debt and find that none of the coefficients is individually significant. However, Figure 5 confirms that there is no correlation between debt levels and sovereign spreads outside the Eurozone and that there is a positive and statistically significant correlation between debt levels and spreads inside the Eurozone (this correlation is however independent of the share of external debt).

It is not clear whether the weak results of column 2 are due to the fact that debt composition does not matter for the relationship between debt levels and spreads or if they are caused by data limitations that do not allow us to conduct differences-in differences estimations. ${ }^{14} \mathrm{We}$ explore this issue by substituting the share of external debt with net foreign assets as a share of GDP. Column 3 shows that countries with large net foreign assets face lower spreads but that the beneficial effect of foreign wealth is larger within the Eurozone. In column 4, we interact net external wealth with debt levels in Eurozone and not Eurozone countries and find that in both types of countries the positive relationship between debt levels and spreads only holds for

\footnotetext{
${ }^{14}$ The data for the share of external debt starts in 1998 and only after 2001 we have data for more than two countries. The euro dummy is thus collinear with the country fixed effects.
} 
countries that do not have large net foreign wealth. However, net foreign assets and liabilities are much more important for countries within the Eurozone, as documented by the fact that the line of Panel a of Figure 6 is much flatter than that of Panel b of the same figure.

Taken together, the results of Tables 8 and 9 confirm that, even in advanced economies, debt vulnerabilities are amplified by the presence of large net external liabilities and that the negative amplifying effect of external liabilities is larger in the Eurozone than in standalone advanced economies. The fact that Eurozone countries are similar to emerging market countries that suffer from original sin confirms the importance of debt composition.

\section{Conclusions}

This paper studies how debt composition and net foreign wealth affects the relationship between sovereign spreads and debt ratios in emerging market and advanced economies. Our results can be summarized with the following five facts: (i) Spreads are positively correlated with debt ratios in both advanced and emerging market countries. However, the correlation between spreads and debt ratios is five times larger in emerging market countries. (ii) There are large difference between Eurozone countries and standalone advanced economies. In Eurozone countries the correlation between debt ratios and spreads is not significantly different from that of emerging market countries. In standalone countries, the correlation between debt ratios and spreads is statistically significant but very small. (iii) The global financial crisis increased the correlation between spreads and debt ratios within the Eurozone but had not effect on the correlation between spreads and debt in standalone countries. (iv) Foreign currency debt is a significant amplifier of debt vulnerabilities. Emerging market countries with low levels of foreign currency debt are characterized by a low correlation between debt levels and spreads while countries with a large share of foreign currency debt levels exhibit a large and statistically significant impact of foreign currency debt on spreads. ( $v$ ) Large foreign liabilities amplify debt vulnerabilities. In advanced economies, this amplifying effect is particularly large within the Eurozone.

The main message of the paper is thus that debt composition, and not only debt levels matter. The paper thus strongly supports the hypothesis that, in the presence of multiple equilibria, the possibility of a bad equilibrium is more likely when a country has liabilities denominated in foreign currency. Our results, also corroborate, Corsetti (2010) and De Grauwe's (2011) idea 
that a monetary union can increase financial fragilities in countries that were previously exempt from original sin.

It is, however, important not to push the analogy of original sin with the euro too far. The European Central Bank does care about financial stability in member countries, a fact clearly demonstrated by its decision to implement the Outright Monetary Transaction (OMT) program. By the same token, it explains why such a program had such large effects on spreads, as it clarified to the market the extent to which the euro differs from original sin.

The paper should also not be interpreted as a criticism to the creation of the euro. While the monetary union may have had a negative effect on financial fragility, it had several positive effects on European integration. Moreover, it is hard to establish a counterfactual. If countries in the Eurozone periphery were standalone countries they could suffer from high interest rates, not because of credit risk but because of exchange rate or inflationary risk. These are factors that we cannot capture in our analysis. 


\section{References}

Aizenman, J, Jinjarak, Y and Park D (2013), "Fundamentals and Sovereign Risk of Emerging Markets", NBER Working paper 18963.

Alper Emre and Lorenzo Forni (2011) "Public Debt in Advanced Economies and its Spillover Effects on Long-term Yields," IMF Working Papers 11/210, International Monetary Fund.

Belhocine, Nazim and Salvatore Dell'Erba (2013) "The Impact of Debt Sustainability and the Level of Debt on Emerging Markets Spreads," IMF WP N. 13/93

Codogno, L., Favero, C., Missale, A., Portes, R., Thum, M., 2003. Yield Spreads on EMU Government Bonds, Economic Policy. Vol. 18, No. 37, pp. 503-532.

Cohen, Daniel. 1993. "Low Investment and Large LDC Debt in the 1980's." American EconomicReview 83(3):437-49.

Cordella, Tito, Luca Antonio Ricci, and Marta Ruiz-Arranz (2010) "Debt Overhang or Debt Irrelevance" IMF Staff Papers, Palgrave Macmillan, vol. 57(1), pages 1-24, April.

Corsetti, Giancarlo (2010) “The 'original sin’ in the Eurozone” VOX EU, May 9.

Cowan, Kevin, Eduardo Levy Yeyati, Ugo Panizza, and Federico Sturzenegger (2006)

"Sovereign Debt in the Americas: New Data and Stylized Facts," RES Working Papers 4480, Inter-American Development Bank, Research Department.

De Grauwe, Paul (2011) The governance of a fragile Eurozone, economic policy, CEPS working documents

De Grauwe, Paul and Yuemei Ji (2013) "Self-fulfilling crises in the Eurozone: An empirical test," Journal of International Money and Finance 34 (2013) 15-36

Du, Wenxin and Schreger, Jesse (2013) “Local Currency Sovereign Risk" unpublished, Harvard University.

Eichengreen, Barry and Ricardo Hausmann (1999) "Exchange Rates and Financial Fragility," Paper presented at the symposium New Challenges for Monetary Policy, August 26-28, Jackson Hole, WY.

Eichengreen, Barry, Ricardo Hausmann, and Ugo Panizza (2005a) "The Pain of Original Sin," in B. Eichengreen and R. Hausmann (eds.) Other People's Money, Chicago University Press

Eichengreen, Barry, Ricardo Hausmann, and Ugo Panizza (2005b) "The Mystery of Original Sin" in B. Eichengreen and R. Hausmann (eds.) Other People's Money, Chicago University Press

Eichengreen, Barry, Ricardo Hausmann, and Ugo Panizza (2007) "Currency Mismatches, Debt Intolerance, and the Original Sin: Why They Are Not the Same and Why It Matters," in: Capital Controls and Capital Flows in Emerging Economies: Policies, Practices and Consequences, National Bureau of Economic Research, Inc. and Chicago University Press, p. 121-170 
Favero, Carlo, Francesco Giavazzi, and Luigi Spaventa, 1997. "High Yields: The Spread on German Interest Rates," Economic Journal, vol. 107(443): 956-85.

Fosu, Augustin Kwasi. 1996. "The Impact of External Debt on Economic Growth in Sub-Saharan Africa." Journal of Development Economics 21(1):93-117.

Goldstein, Morris and Philip Turner (2004) Controlling Currency Mismatches in Emerging Markets, Peterson Institute for International Economics, Washington DC.

González-Rozada Martín and EduardoLevy Yeyati, (2008). "Global Factors and Emerging Market Spreads," Economic Journal, Royal Economic Society, vol. 118(533), pages 1917-1936, November.

Green, Joshua and Delano Villanueva. 1991. "Private Investment in Developing Countries: An Empirical Analysis." IMF Staff Papers 38(1):33-58.

Greenlaw, David, James D. Hamilton, Peter Hooper, and Frederic S. Mishkin (2013), "Crunch Time: Fiscal Crises and the Role of Monetary Policy," paper written for "U.S. Monetary Policy Forum," a conference sponsored by the University of Chicago Booth School of Business, held in New York, February 22

Gros (this volume)

Hausmann, Ricardo and Ugo Panizza (2003) "On the determinants of Original Sin: an empirical investigation," Journal of International Money and Finance, vol. 22(7): 957-990.

Hausmann, Ricardo and Ugo Panizza (2011) "Redemption or Abstinence? Original Sin, Currency Mismatches and Counter Cyclical Policies in the New Millennium," Journal of Globalization and Development, De Gruyter, vol. 2(1), pages 1-35, August.

Hausmann, Ricardo, Ugo Panizza, and Ernesto Stein (2001) "Why do countries float the way they float?" Journal of Development Economics, vol. 66(2): 387-414.

Herndon, Thomas, Michael Ash and Robert Pollin (2013), "Does high public debt consistently stifle economic growth? A critique of Reinhart and Rogoff", PERI working paper $n^{\circ} 322$, April.

Ichiue, Hibiki, and Yuhei Shimizu (2012). "Determinants of Long-term Yields: A PanelData Analysis of Major Countries." Working paper, Bank of Japan.

Jeanne, Olivier and Anastasia Guscina (2006) "Government Debt in Emerging Market Countries: A New Data Set," IMF Working Papers 06/98, International Monetary Fund

Krugman, P. 1988, "Financing Versus Forgiving a Debt Overhang," Journal of DevelopmentEconomics, No. 29, pp. 253-68.

Laubach, Thomas (2009). "New Evidence on the Interest Rate Effects of Budget Deficitsand Debt," Journal of the European Economic Association 7, 858-885.

Muellbauer (this volume) 
Panizza, Ugo (2008) "Domestic and External Public Debt in Developing Countries," UNCTAD Discussion Papers 188.

Panizza, Ugo and Andrea F Presbitero (2012), "Public debt and economic growth: is there a causal effect?", MoFiR working papers, $n^{\circ} 65$.

Panizza, Ugo and Andrea F Presbitero (2013), "Public debt and economic growth in advanced economies: A survey", Swiss Journal of Economics and Statistics, forthcoming.

Pattillo, Catherine, Hélène Poirson, and Luca Antonio Ricci (2003) “ Through What Channels Does External Debt Affects Growth?” Brookings Trade Forum, pp. 229-58.

Pattillo, Catherine, Hélène Poirson, and Luca Antonio Ricci (2011) "External Debt and Growth," Review of Economics and Institutions, vol. 2(3).

Presbitero, Andrea (2012) "Total Public Debt and Growth in Developing Countries," The European Journal of Development Research, Palgrave Macmillan, vol. 24(4), pages 606-626, September.

Reinhart, Carmen M and Kenneth S Rogoff (2010), "Growth in a Time of Debt", American Economic Review: Papers and Proceedings, 100(2):573-578.

Reinhart, Carmen, Kenneth Rogoff, and Miguel Savastano (2003) "Debt Intolerance," Brookings Papers on Economic Activity, vol. 34(1): 1-74.

Sachs, J. D., 1988, "The Debt Overhang of Developing Countries," in. Debt Stabilization andDevelopment: Essays in Memory of Carlos Diaz-Alejandro, ed. by G. Calvo, R. Findlay, P. Kouri, and J. Braga de Macedo (Oxford: Basil Blackwell).

Savvides, Andreas (1992) "Investment Slowdown in Developing Countries during the 1980s: Debt Overhang or Foreign Capital Inflows?" Kyklos 45(3):363-78.

Whelan (this volume) 


\section{Appendix: External versus domestic debt ${ }^{15}$}

There are three possible definitions of external and domestic debt. The first definition focuses on the currency in which the debt is issued (with external debt defined as foreign currency debt). The second concentrates on the residence of the creditor (external debt is debt owed to nonresidents). The third relates to the place of issuance and the legislation that regulates the debt contract (external debt is debt issued in foreign countries and under the jurisdiction of a foreign court).

The first definition does not seem appropriate because several countries issue foreign currency denominated debt in the domestic markets and have recently started to issue domestic currency denominated debt in international markets. Moreover, this definition is problematic for countries that adapt the currency of another country. Accordingly, a definition based on the currency composition of public debt would be hard to implement given the limited information on the currency composition of domestic debt.

The second definition is the one which is officially adopted by the main compilers of statistical information on public debt. The External Debt Statistics: Guide for Compilers and Users jointly published by the BIS, Eurostat, IMF, OECD, Paris Club, UNCTAD and the World Bank states that: "Gross external debt, at any given time, is the outstanding amount of those actual event, and not contingent liabilities that require payment(s) of principal and/or interest by the debtor at some point(s) in the future and that are owed to non-residents by residents of an economy". This definition makes sense from a theoretical point of view because it focuses on the transfer of resources between residents and non-residents, it allows to measure the amount of international risk sharing and the income effects of variations in the stock of debt, and to evaluate the political cost of a default on public debt.

This paper uses sources that adopt this second definition of external debt. However, while the data for advanced economies tend to be reliable, few developing countries have the capacity to identify the ultimate holders of their bonds and end up reporting figures for external and domestic debt by using information on the place of issuance and jurisdiction that regulates the debt contract. This would be irrelevant if there were a close match between the place of issuance and the residency of the ultimate holder, as it used to be the case in the past.

\footnotetext{
${ }^{15}$ This appending draws from Panizza (2008) and Panizza and Presbitero (2013)
} 
However, there is evidence that more and more international investors are entering the domestic markets of developing countries and that domestic investors often hold bonds issued in international market creating a mismatch between actual and reported external debt. Another issue relates to the definition of public debt. Should researchers focus on gross or net debt? Should they concentrate on explicit debt, or also consider the government's implicit liabilities? Should standard measures of public debt also include the expected value of the government's contingent liabilities (consider the sudden debt explosions in Iceland, Ireland, and Spain)?

The difference between gross and net debt can be very large. At the end of 2012, average gross debt in OECD countries was close to 110 percent of the group's GDP, but net debt was almost 40 percentage points lower than gross debt. While net debt may seem the best measure of government indebtedness, calculating net debt requires a precise evaluation of the government's assets and liability. This is a difficult exercise, full of practical and conceptual challenges. As a consequence, while the definition of gross debt is fairly homogenous across countries, each country has its own definition of net debt.

Since net debt is hard to compute and rarely comparable across countries, most papers that study the relationship between debt and growth use gross debt, even if this measure of debt is not a good indicator of the government's financial situation. Moreover, even data on gross debt are not strictly comparable, as definitions of government vary across countries. 
Table 1: Summary Statistics

\begin{tabular}{|c|c|c|c|c|c|}
\hline & Mean & Std. Dev. & Min & Max & N. Obs. \\
\hline \multicolumn{6}{|c|}{ DEVELOPING COUNTRIES } \\
\hline \multicolumn{6}{|c|}{ Full Sample } \\
\hline Spread (bps) & 358 & 283 & 25 & 2049 & 709 \\
\hline Debt-to-GDP (\%) & 42 & 21 & 0 & 103 & 716 \\
\hline Debt-to-Revenues (\%) & 170 & 94 & 15 & 591 & 666 \\
\hline Fundamentals (index) & 0.33 & 0.09 & 0.00 & 1.00 & 591 \\
\hline Share of External Debt & 0.41 & 0.20 & 0.03 & 0.95 & 525 \\
\hline Share of External Debt times Original Sin & 0.37 & 0.22 & 0.00 & 0.94 & 457 \\
\hline Net Foreign Assets ( $\%$ of GDP) & -0.37 & 0.30 & -1.42 & 0.46 & 871 \\
\hline \multicolumn{6}{|c|}{ Pre 2008} \\
\hline Spread (bps) & 342 & 260 & 25 & 1483 & 506 \\
\hline Debt-to-GDP (\%) & 43 & 22 & 0 & 103 & 514 \\
\hline Debt-to-Revenues (\%) & 175 & 96 & 15 & 592 & 464 \\
\hline Fundamentals (index) & 0.34 & 0.09 & 0.07 & 0.60 & 394 \\
\hline \multicolumn{6}{|c|}{ Post 2008} \\
\hline Spread (bps) & 398 & 330 & 39 & 2049 & 203 \\
\hline Debt-to-GDP (\%) & 39 & 19 & 5 & 82 & 202 \\
\hline Debt-to-Revenues (\%) & 157 & 88 & 17 & 478 & 202 \\
\hline Fundamentals (index) & 0.33 & 0.12 & 0.54 & 0.54 & 197 \\
\hline \multicolumn{6}{|c|}{ ADVANCED ECONOMIES } \\
\hline \multicolumn{6}{|c|}{ Full Sample } \\
\hline Spread (bps) & 23 & 75 & -105 & 664 & 523 \\
\hline Debt-to-GDP (\%) & 73 & 33 & 12 & 219 & 590 \\
\hline Debt-to-Revenues (\%) & 175 & 108 & 32 & 681 & 530 \\
\hline Fundamentals (index) & 0.65 & 0.10 & 0.42 & 1.00 & 470 \\
\hline Share of External Debt & 0.40 & 0.19 & 0.03 & 0.90 & 280 \\
\hline Net Foreign Assets ( $\%$ of GDP) & -0.13 & 0.33 & -1.68 & 0.77 & 614 \\
\hline \multicolumn{6}{|c|}{ Pre 2008} \\
\hline Spread (bps) & 11 & 25 & -101 & 148 & 411 \\
\hline Debt-to-GDP (\%) & 70 & 30 & 11 & 183 & 462 \\
\hline Debt-to-Revenues (\%) & 164 & 97 & 32 & 611 & 402 \\
\hline Fundamentals (index) & 0.62 & 0.08 & 0.42 & 0.80 & 342 \\
\hline \multicolumn{6}{|c|}{ Post 2008} \\
\hline Spread (bps) & 66 & 148 & -105 & 664 & 112 \\
\hline Debt-to-GDP (\%) & 83 & 41 & 13 & 219 & 128 \\
\hline Debt-to-Revenues (\%) & 209 & 133 & 37 & 681 & 128 \\
\hline Fundamentals (index) & 0.72 & 0.10 & 0.49 & 1.00 & 128 \\
\hline \multicolumn{6}{|c|}{ Pre 2008 No Eurozone } \\
\hline Spread (bps) & 15 & 27 & -101 & 148 & 259 \\
\hline Debt-to-GDP (\%) & 71 & 33 & 12 & 183 & 298 \\
\hline Debt-to-Revenues (\%) & 175 & 118 & 33 & 611 & 238 \\
\hline Fundamentals (index) & 0.63 & 0.09 & 0.46 & 0.80 & 178 \\
\hline \multicolumn{6}{|c|}{ Post 2008 No Eurozone } \\
\hline Spread (bps) & -25 & 30 & -105 & 35 & 48 \\
\hline Debt-to-GDP (\%) & 83 & 55 & 13 & 219 & 56 \\
\hline Debt-to-Revenues (\%) & 235 & 189 & 37 & 681 & 56 \\
\hline Fundamentals (index) & 0.74 & 0.11 & 0.54 & 0.93 & 56 \\
\hline \multicolumn{6}{|c|}{ Pre 2008 Eurozone } \\
\hline Spread (bps) & 7 & 18 & -29 & 135 & 152 \\
\hline Debt-to-GDP (\%) & 68 & 24 & 22 & 129 & 164 \\
\hline Debt-to-Revenues (\%) & 150 & 50 & 63 & 289 & 164 \\
\hline Fundamentals (index) & 0.62 & 0.07 & 0.42 & 0.75 & 164 \\
\hline \multicolumn{6}{|c|}{ Post 2008 Eurozone } \\
\hline Spread (bps) & 134 & 164 & -39 & 664 & 64 \\
\hline Debt-to-GDP (\%) & 83 & 25 & 27 & 133 & 72 \\
\hline Debt-to-Revenues (\%) & 190 & 59 & 78 & 343 & 72 \\
\hline Fundamentals (index) & 0.72 & 0.09 & 0.50 & 1.00 & 72 \\
\hline
\end{tabular}


Table 2: Sovereign Spreads and Fundamentals in Emerging Markets

\begin{tabular}{|c|c|c|c|c|c|c|}
\hline & (1) & (2) & (3) & (4) & (5) & (6) \\
\hline \multirow[t]{2}{*}{ Debt to GDP } & $4.469 * * *$ & $4.229 * * *$ & & & & \\
\hline & $(0.714)$ & $(0.742)$ & & & & \\
\hline \multirow[t]{2}{*}{ Debt to GDP * Crisis } & & 1.111 & & & & \\
\hline & & $(0.896)$ & & & & \\
\hline \multirow[t]{2}{*}{ Debt to Revenue } & & & $1.077 * * *$ & $0.979 * * *$ & & \\
\hline & & & $(0.176)$ & $(0.172)$ & & \\
\hline \multirow[t]{2}{*}{ Debt to Revenue ${ }^{*}$ Crisis } & & & & 0.426 & & \\
\hline & & & & $(0.270)$ & & \\
\hline \multirow[t]{2}{*}{ Fundamentals } & & & & & $558.7 * *$ & $684.2 * * *$ \\
\hline & & & & & $(237.9)$ & $(250.5)$ \\
\hline \multirow[t]{2}{*}{ Fundamentals* Crisis } & & & & & & -253.0 \\
\hline & & & & & & $(193.4)$ \\
\hline \multirow[t]{2}{*}{ Constant } & $507.6 * *$ & $509.5 * *$ & $155.4 * * *$ & $203.5 * * *$ & $149.8^{*}$ & 105.8 \\
\hline & $(220.5)$ & $(220.0)$ & $(27.02)$ & $(27.82)$ & $(87.36)$ & $(91.00)$ \\
\hline Observations & 627 & 627 & 607 & 607 & 560 & 560 \\
\hline R-squared & 0.695 & 0.696 & 0.685 & 0.688 & 0.682 & 0.683 \\
\hline $\mathrm{N}$ of countries & 26 & 26 & 26 & 26 & 26 & 26 \\
\hline
\end{tabular}

Estimations with country and period fixed effects. Robust standard errors in parentheses, $* * * \mathrm{p}<0.01, * * \mathrm{p}<0.05, *$ $\mathrm{p}<0.1$ 
Table 3: Sovereign Spreads and Public Debt in Advanced Economies

\begin{tabular}{|c|c|c|c|c|c|c|c|c|}
\hline & $(1)$ & $(2)$ & (3) & $(4)^{\prime}$ & $(5)$ & $(6)$ & $(7)$ & $(8)$ \\
\hline \multirow[t]{2}{*}{ Debt to GDP } & $0.602 * *$ & $0.466^{*}$ & $0.305 *$ & $1.107 * *$ & $0.519 * * *$ & $0.733 * *$ & $0.113 * *$ & $0.0981 *$ \\
\hline & $(0.288)$ & $(0.280)$ & $(0.166)$ & $(0.470)$ & $(0.160)$ & $(0.288)$ & $(0.0512)$ & $(0.0518)$ \\
\hline \multirow[t]{2}{*}{ Debt to GDP $*$ Crisis } & & 0.263 & & & -0.221 & 0.994 & 0.0370 & 0.0503 \\
\hline & & $(0.282)$ & & & $(0.145)$ & $(0.634)$ & $(0.0463)$ & $(0.0468)$ \\
\hline \multirow[t]{2}{*}{ Debt to GDP * Euro } & & & $2.267 * * *$ & $6.395 * * *$ & $0.866^{* *}$ & $3.302 * * *$ & 0.0740 & 0.0571 \\
\hline & & & $(0.458)$ & $(1.871)$ & $(0.397)$ & $(1.244)$ & $(0.0774)$ & $(0.0731)$ \\
\hline \multirow[t]{2}{*}{$\begin{array}{l}\text { Debt to GDP * } \\
\text { Crisis*Euro }\end{array}$} & & & & & $1.734 * * *$ & $3.336 * * *$ & $0.929 * * *$ & $0.965 * * *$ \\
\hline & & & & & $(0.186)$ & $(0.618)$ & $(0.0438)$ & $(0.0416)$ \\
\hline \multirow[t]{2}{*}{ Euro } & & & $-139 * * *$ & $-426 * * *$ & $-72.4 * *$ & $-266 * * *$ & -5.088 & -7.838 \\
\hline & & & $(34.54)$ & $(131.9)$ & $(30.90)$ & $(97.13)$ & $(6.549)$ & $(6.368)$ \\
\hline \multirow[t]{2}{*}{ Constant } & -26.45 & -16.12 & 1.548 & -34.06 & -18.48 & -14.00 & $-27.65 * * *$ & $-28.78 * * *$ \\
\hline & $(21.36)$ & $(20.63)$ & $(17.38)$ & $(40.68)$ & $(14.69)$ & $(29.71)$ & $(5.897)$ & $(5.915)$ \\
\hline Observations & 504 & 504 & 504 & 567 & 504 & 567 & 504 & 567 \\
\hline R-squared & 0.363 & 0.365 & 0.465 & 0.452 & 0.596 & 0.539 & 0.716 & 0.770 \\
\hline N. of countries & 15 & 15 & 15 & 17 & 15 & 17 & 15 & 17 \\
\hline Estimation Method & & & untry and $\mathrm{p}$ & iod fixed & ffects & & $\begin{array}{r}\text { Robust res } \\
\text { co } \\
\text { and period } \\
\end{array}$ & $\begin{array}{l}\text { ssion with } \\
\text { try } \\
\text { xed effects }\end{array}$ \\
\hline
\end{tabular}

Robust standard errors in parentheses, ${ }^{* * *} \mathrm{p}<0.01, * * \mathrm{p}<0.05, * \mathrm{p}<0.1$ 
Table 4: Sovereign Spreads, Public Debt, and Fundamentals in country-by-country regressions (1999-2012)

\begin{tabular}{|c|c|c|c|c|c|c|}
\hline & \multicolumn{3}{|c|}{ Spreads and Public debt over GDP } & \multicolumn{3}{|c|}{ Spreads and Index of Fundamentals } \\
\hline & Coeff & t-stat & N.Obs & Coeff & t-stat & N.Obs \\
\hline & \multicolumn{6}{|c|}{ Non Eurozone Countries } \\
\hline AUS & 0.63 & 0.48 & 27 & -566.90 & 2.85 & 27 \\
\hline CAN & 0.03 & 0.06 & 27 & -192.26 & 3.50 & 27 \\
\hline DNK & 0.23 & 0.30 & 27 & -252.65 & 2.44 & 27 \\
\hline GBR & -0.22 & 1.15 & 27 & -24.55 & 0.54 & 27 \\
\hline JPN & -0.67 & 4.65 & 27 & -269.61 & 3.16 & 27 \\
\hline \multirow[t]{2}{*}{ SWE } & 1.32 & 2.14 & 27 & -268.23 & 2.10 & 27 \\
\hline & \multicolumn{6}{|c|}{ Eurozone Countries } \\
\hline AUT & 1.36 & 1.48 & 27 & 246.39 & 0.87 & 27 \\
\hline BEL & 1.59 & 1.12 & 27 & 512.82 & 4.75 & 27 \\
\hline ESP & 6.85 & 3.27 & 27 & 1410.22 & 5.73 & 27 \\
\hline FIN & 1.60 & 2.99 & 27 & 195.805 & 3.22 & 27 \\
\hline FRA & 1.96 & 6.58 & 27 & 306.579 & 4.33 & 27 \\
\hline GRC & 34.97 & 11.38 & 27 & & & \\
\hline ITA & 7.26 & 3.08 & 27 & 808.86 & 2.11 & 27 \\
\hline NLD & 0.93 & 2.98 & 27 & 174.55 & 2.69 & 27 \\
\hline PRT & 11.44 & 6.98 & 27 & & & \\
\hline
\end{tabular}


Table 5: Sovereign Spreads and Public Debt in Advanced Economies

\begin{tabular}{|c|c|c|c|c|c|c|}
\hline & (1) & (2) & (3) & (4) & (5) & (6) \\
\hline \multirow{2}{*}{ Fundamentals } & $594.0 * * *$ & $362.5 * * *$ & -19.76 & -385.7 & $190.5^{* *}$ & -82.34 \\
\hline & $(151.6)$ & $(123.1)$ & $(114.6)$ & $(253.9)$ & $(88.97)$ & $(234.7)$ \\
\hline \multirow{2}{*}{ Fundamentals* Crisis } & & $407.9 * * *$ & & & $313.4 * * *$ & $956.5 * * *$ \\
\hline & & $(139.5)$ & & & $(102.4)$ & $(297.6)$ \\
\hline \multirow[t]{2}{*}{ Fundamentals* Euro } & & & $889.3 * * *$ & $1,428 * * *$ & 126.7 & 80.74 \\
\hline & & & $(121.1)$ & $(246.6)$ & $(116.6)$ & $(211.2)$ \\
\hline \multirow[t]{2}{*}{ Fundamentals* Crisis*Euro } & & & & & $212.7 * * *$ & $352.2 * * *$ \\
\hline & & & & & $(25.57)$ & $(71.23)$ \\
\hline \multirow[t]{2}{*}{ Euro } & & & $-528.9 * * *$ & $-803.8 * * *$ & -77.50 & 24.65 \\
\hline & & & $(76.43)$ & $(135.8)$ & $(72.76)$ & $(149.2)$ \\
\hline \multirow[t]{2}{*}{ Constant } & $-346.1 * * *$ & $-206.0 * * *$ & 23.70 & $259.6^{*}$ & $-103.3 *$ & 75.08 \\
\hline & $(92.50)$ & $(75.27)$ & $(69.82)$ & $(156.6)$ & $(53.91)$ & $(143.9)$ \\
\hline Observations & 410 & 410 & 410 & 468 & 410 & 468 \\
\hline R-squared & 0.402 & 0.430 & 0.532 & 0.365 & 0.633 & 0.431 \\
\hline N. of countries & 15 & 15 & 15 & 17 & 15 & 17 \\
\hline
\end{tabular}

Estimations with country and period fixed effects. Robust standard errors in parentheses, $* * * \mathrm{p}<0.01, * * \mathrm{p}<0.05, *$ $\mathrm{p}<0.1$

Table 6: Spread and Debt Composition in Emerging Market Countries

\begin{tabular}{|c|c|c|c|c|c|c|}
\hline & (1) & (2) & (3) & (4) & (5) & (6) \\
\hline \multirow{2}{*}{ Debt to GDP } & $4.268 * * *$ & $2.970 * *$ & $4.489 * * *$ & 1.884 & $4.593 * * *$ & 1.355 \\
\hline & $(0.785)$ & $(1.501)$ & $(0.635)$ & $(1.197)$ & $(0.661)$ & $(0.970)$ \\
\hline \multirow[t]{2}{*}{ SH_ED } & $207.2 * * *$ & 97.06 & & & 110.1 & \\
\hline & $(64.42)$ & $(100.5)$ & & & $(104.3)$ & \\
\hline \multirow[t]{2}{*}{ SH_ED*Debt to GDP } & & 2.599 & & & & 0.738 \\
\hline & & $(2.301)$ & & & & $(2.122)$ \\
\hline \multirow[t]{2}{*}{ SH_EDOS } & & & $271.9 * * *$ & 68.18 & $191.7 * *$ & \\
\hline & & & $(56.02)$ & $(90.29)$ & $(92.87)$ & \\
\hline \multirow[t]{2}{*}{ SH_EDOS*Debt to GDP } & & & & $5.734 * * *$ & & $6.348 * * *$ \\
\hline & & & & $(2.142)$ & & $(2.119)$ \\
\hline \multirow[t]{2}{*}{ Constant } & $218.5 * * *$ & $271.3 * * *$ & -35.60 & 45.69 & -46.56 & $77.61 * *$ \\
\hline & $(45.03)$ & $(61.33)$ & $(41.48)$ & $(51.74)$ & $(44.45)$ & $(32.55)$ \\
\hline Observations & 456 & 456 & 395 & 395 & 395 & 395 \\
\hline R-squared & 0.738 & 0.739 & 0.792 & 0.795 & 0.792 & 0.795 \\
\hline
\end{tabular}

Estimations with country and period fixed effects. Robust standard errors in parentheses, $* * * p<0.01, * * p<0.05, *$ $\mathrm{p}<0.1$ 
Table 7: Spread and Net Foreign Assets in Emerging Market Countries

\begin{tabular}{|l|c|c|c|}
\hline & $(1)$ & $(2)$ & $(3)$ \\
\hline Debt to GDP & $5.089^{* * *}$ & 1.999 & $1.716^{*}$ \\
\hline & $(0.718)$ & $(1.231)$ & $(1.019)$ \\
\hline NFA_GDP*Debt to GDP & & $-6.779^{* * *}$ & $(0.881)$ \\
\hline & & $(1.706)$ & \\
\hline NFA_GDP & $-154.6^{* * *}$ & 150.4 & $4.455^{* * *}$ \\
\hline & $(48.23)$ & $(96.34)$ & $(1.458)$ \\
\hline SH_EDOS*Debt to GDP & & & $281.0^{* * *}$ \\
\hline & & & $(35.57)$ \\
\hline Constant & $415.2^{*}$ & $505.5^{* *}$ & 371 \\
\hline & $(227.0)$ & $(203.3)$ & 0.804 \\
\hline Observations & 600 & 600 & 0.707 \\
\hline R-squared & 0.698 & & $0.05, *$ \\
\hline
\end{tabular}

Estimations with country and period fixed effects. Robust standard errors in parentheses, ${ }^{* * *} \mathrm{p}<0.01,{ }^{* *} \mathrm{p}<0.05$, * $\mathrm{p}<0.1$

Table 8: Spread, External Debt and Net Foreign Assets in Advanced Economies

\begin{tabular}{|l|c|c|c|c|c|}
\hline & $(1)$ & $(2)$ & $(3)$ & $(4)$ & $(5)$ \\
\hline Debt to GDP & -0.0571 & $-1.869^{* * *}$ & $0.530^{* *}$ & $0.926^{* * *}$ & $-1.885^{* * *}$ \\
\hline SH_ED & $(0.652)$ & $(0.526)$ & $(0.245)$ & $(0.215)$ & $(0.604)$ \\
\hline & -77.92 & $-346.1^{* * *}$ & & & $-366.2^{* * *}$ \\
\hline SH_ED* Debt to GDP & $(62.00)$ & $(82.28)$ & & & $(86.55)$ \\
\hline & & $6.187^{* * *}$ & & & $6.239^{* * *}$ \\
\hline NFA_GDP* Debt to GDP & & $(1.351)$ & & & $(1.467)$ \\
\hline & & & & $-2.588^{* * *}$ & -0.955 \\
\hline NFA_GDP & & & & $(0.387)$ & $(0.604)$ \\
\hline & & & $-103.9^{* * *}$ & $85.07^{* * *}$ & -50.93 \\
\hline Constant & & & $(25.18)$ & $(23.20)$ & $(54.99)$ \\
\hline & 88.00 & $143.3^{* *}$ & $-42.47^{* *}$ & $-67.81^{* * *}$ & $113.1 *$ \\
\hline Observations & $(70.98)$ & $(62.21)$ & $(21.39)$ & $(21.60)$ & $(64.13)$ \\
\hline R-squared & 243 & 243 & 504 & 504 & 243 \\
\hline
\end{tabular}

Estimations with country and period fixed effects. Robust standard errors in parentheses, ${ }^{* * *} \mathrm{p}<0.01, * * \mathrm{p}<0.05$, * $\mathrm{p}<0.1$ 
Table 9: Spread, External Debt and Net Foreign Assets in the Eurozone

\begin{tabular}{|c|c|c|c|c|}
\hline & (1) & (2) & (3) & (4) \\
\hline \multirow[t]{2}{*}{ Debt to GDP*(1-Euro) } & -0.822 & -0.539 & $0.478 * *$ & $0.331 *$ \\
\hline & $(0.569)$ & $(0.765)$ & $(0.212)$ & $(0.181)$ \\
\hline \multirow[t]{2}{*}{ Debt to GDP*Euro } & $3.306^{* * *}$ & 2.996 & $1.293 * * *$ & $1.687 * * *$ \\
\hline & $(1.067)$ & $(1.833)$ & $(0.318)$ & $(0.343)$ \\
\hline \multirow[t]{2}{*}{ SH_ED*(1-Euro) } & -118.7 & & & \\
\hline & $(77.57)$ & & & \\
\hline \multirow[t]{2}{*}{ SH_ED*Euro } & $132.8^{* *}$ & & & \\
\hline & $(60.74)$ & & & \\
\hline \multirow[t]{2}{*}{ SH_ED* Debt to GDP*(1-Euro) } & & -1.506 & & \\
\hline & & $(2.902)$ & & \\
\hline \multirow[t]{2}{*}{ SH_ED* Debt to GDP*Euro } & & 0.266 & & \\
\hline & & $(2.449)$ & & \\
\hline \multirow[t]{2}{*}{ NFA_GDP*(1-Euro) } & & & $-62.30^{* * *}$ & \\
\hline & & & $(23.63)$ & \\
\hline \multirow[t]{2}{*}{ NFA_GDP*Euro } & & & $-91.56^{* * *}$ & \\
\hline & & & $(24.00)$ & \\
\hline \multirow[t]{2}{*}{ NFA_GDP* Debt to GDP*(1-Euro) } & & & & $-1.397 * * *$ \\
\hline & & & & $(0.300)$ \\
\hline \multirow[t]{2}{*}{ NFA_GDP* Debt to GDP*Euro } & & & & $-2.494 * * *$ \\
\hline & & & & $(0.500)$ \\
\hline \multirow[t]{2}{*}{ SH_ED } & & 51.33 & & \\
\hline & & $(129.9)$ & & \\
\hline \multirow[t]{2}{*}{ Euro } & & & & $-94.51 * * *$ \\
\hline & & & & $(23.70)$ \\
\hline \multirow[t]{2}{*}{ NFA_GDP } & & & & $69.30^{* * *}$ \\
\hline & & & & $(26.32)$ \\
\hline \multirow[t]{2}{*}{ Constant } & -58.68 & -48.18 & -31.49 & -10.18 \\
\hline & $(76.52)$ & $(83.84)$ & $(20.12)$ & $(19.28)$ \\
\hline Observations & 243 & 243 & 504 & 504 \\
\hline R-squared & 0.707 & 0.702 & 0.477 & 0.574 \\
\hline
\end{tabular}


Figure 1: Correlation between public debt and sovereign spreads in advanced economies

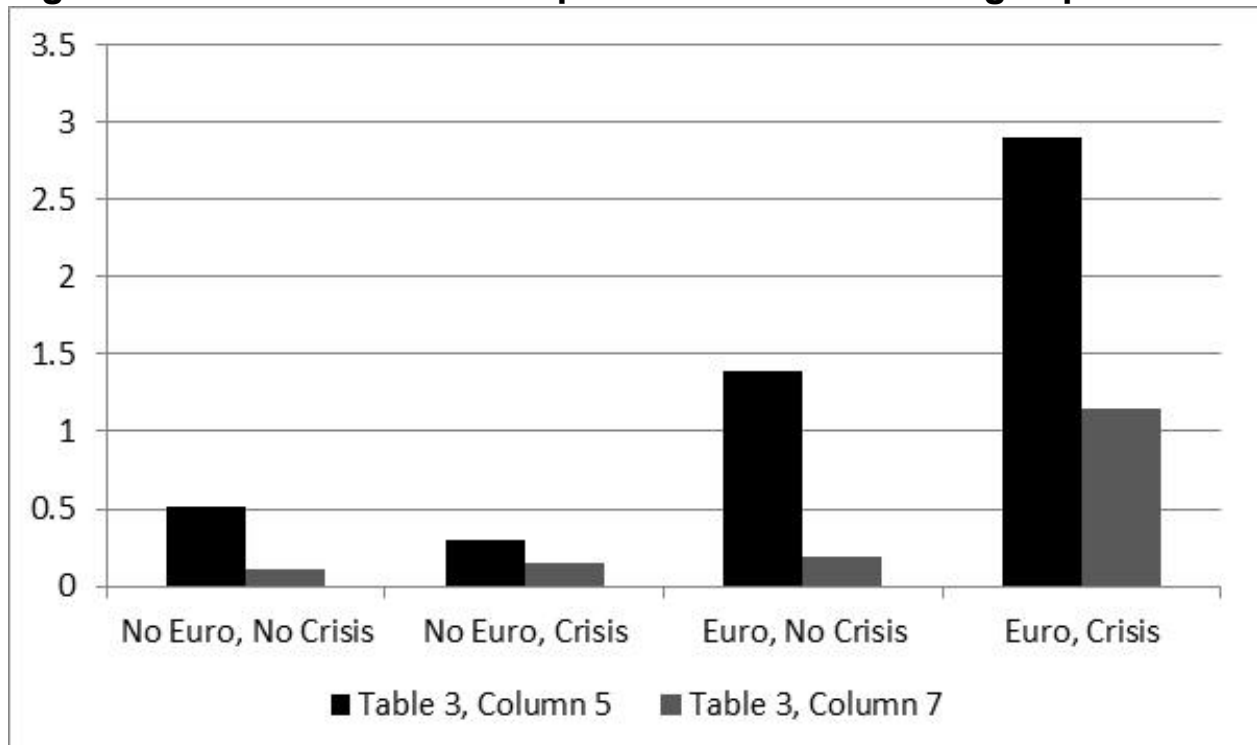

This graph plots the correlation between public debt and spreads in advanced economies inside and outside the Eurozone. The graph is based on the estimations of Table 3 . The dark bars are from the coefficients of column 5 and the light bars from the robust regression of column 7 . 
Figure 2: Sovereign spreads and public debt at different shares of external debt (emerging market countries)

a. Share of Ext. Debt

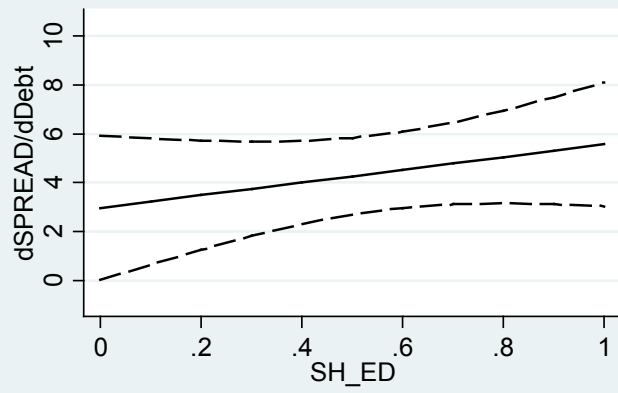

c. Share of Ext. Debt

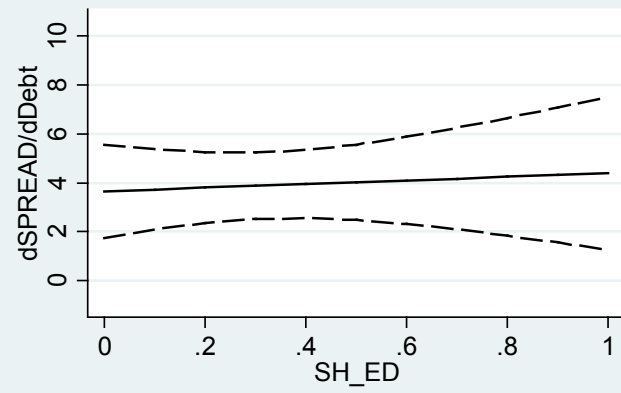

b. Share of FC. Ext. Debt

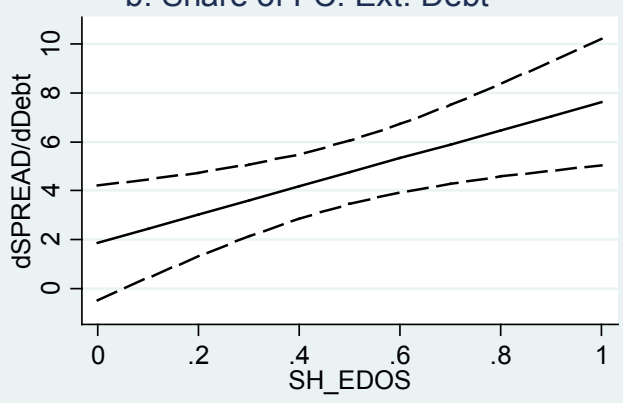

d. Share of FC. Ext. Debt

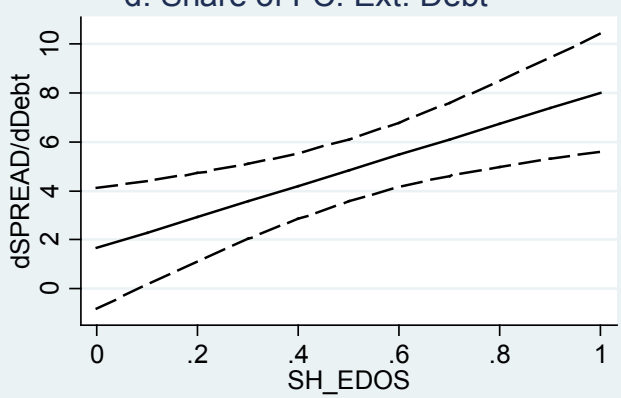

This figure shows the relationship between sovereign spreads and public debt at different levels of external debt (SH_ED) and foreign currency external debt (SH_ED). The solid line plots the point estimate and the dashed lines are 95 percent confidence intervals. Panel $a$ is based on column 2 of Table 6 , panel $b$ is based on column 4 of Table 6 and panels $c$ and $d$ are based on column 6 of Table 6. 
Figure 3: Sovereign spreads and public debt at different levels of net foreign wealth (emerging market countries)

a. Net For. Assets

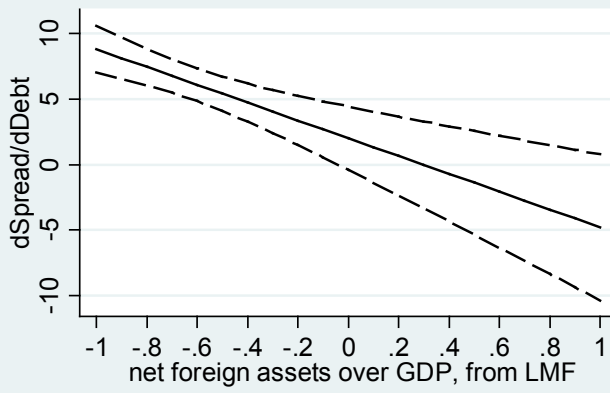

c. Net For. Assets

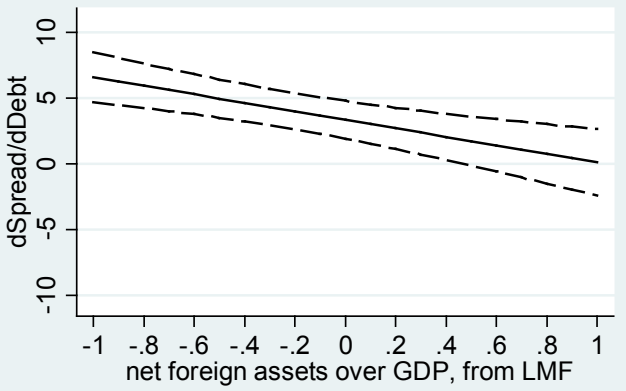

b. Share of FC. Ext. Debt

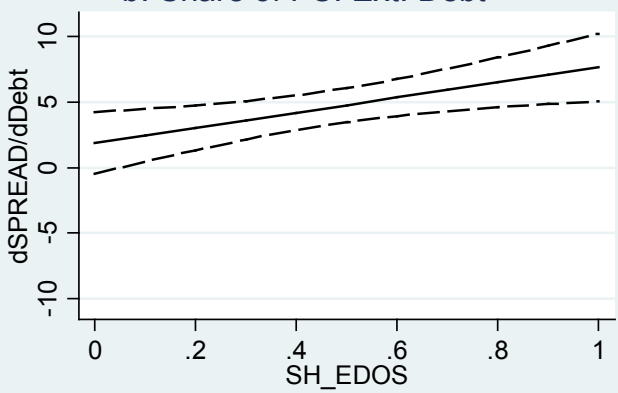

d. Share of FC. Ext. Debt

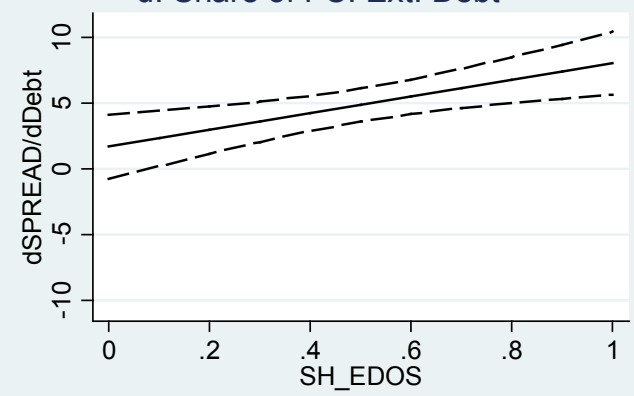

This figure shows the relationship between sovereign spreads and public debt at different levels of net external wealth and foreign currency external debt (SH_ED). The solid line plots the point estimate and the dashed lines are 95 percent confidence intervals. Panel a is based on column 2 of Table 7, panel $b$ is based on column 2 of Table 6 (this is the same as panel b of Figure 2 and is included here to facilitate comparisons with Panel $d$ ), and panels $c$ and $d$ are based on column 3 of Table 7 . 
Figure 4: Sovereign spreads and public debt at different shares of external debt and external wealth (advanced economies)

a. Share of Ext. Debt.

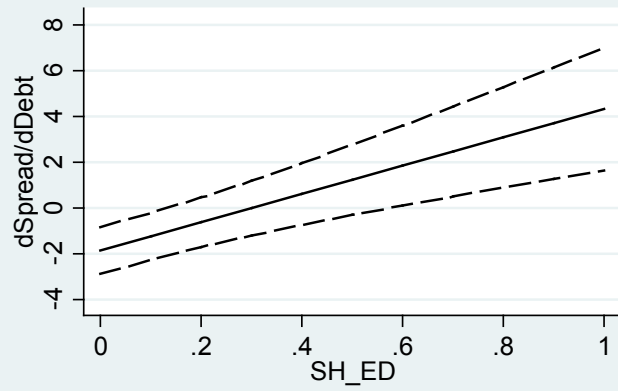

c. Share of Ext. Debt

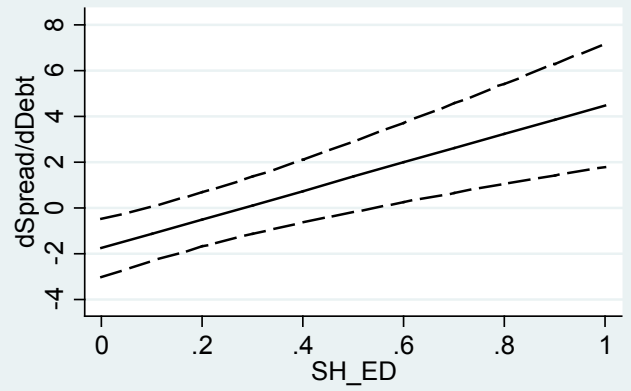

b. Net For. Assets

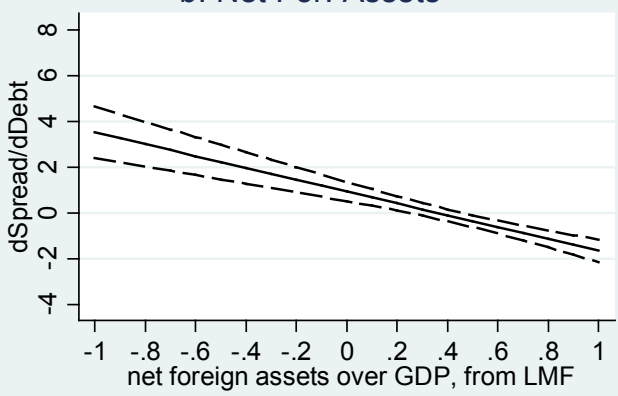

d. Net For. Assets

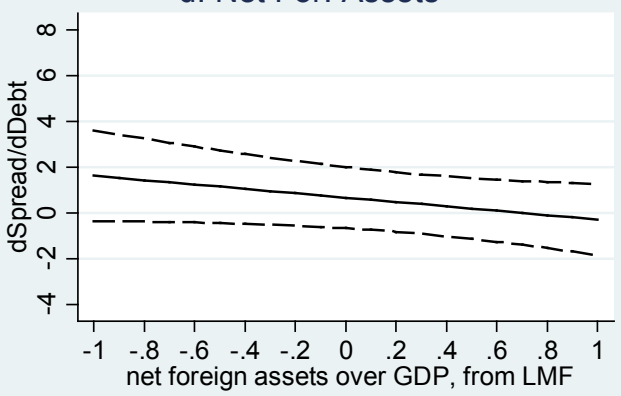

This figure shows the relationship between sovereign spreads and public debt at different levels of new external wealth and external debt. The solid line plots the point estimate and the dashed lines are 95 percent confidence intervals. Panel $a$ is based on column 2 of Table 8 , panel $b$ is based on column 4 of Table 8 , and panels $c$ and $d$ are based on column 5 of Table 8. 
Figure 5: Sovereign spreads and public debt at different levels of external debt in Euro and Non-Euro advanced economies
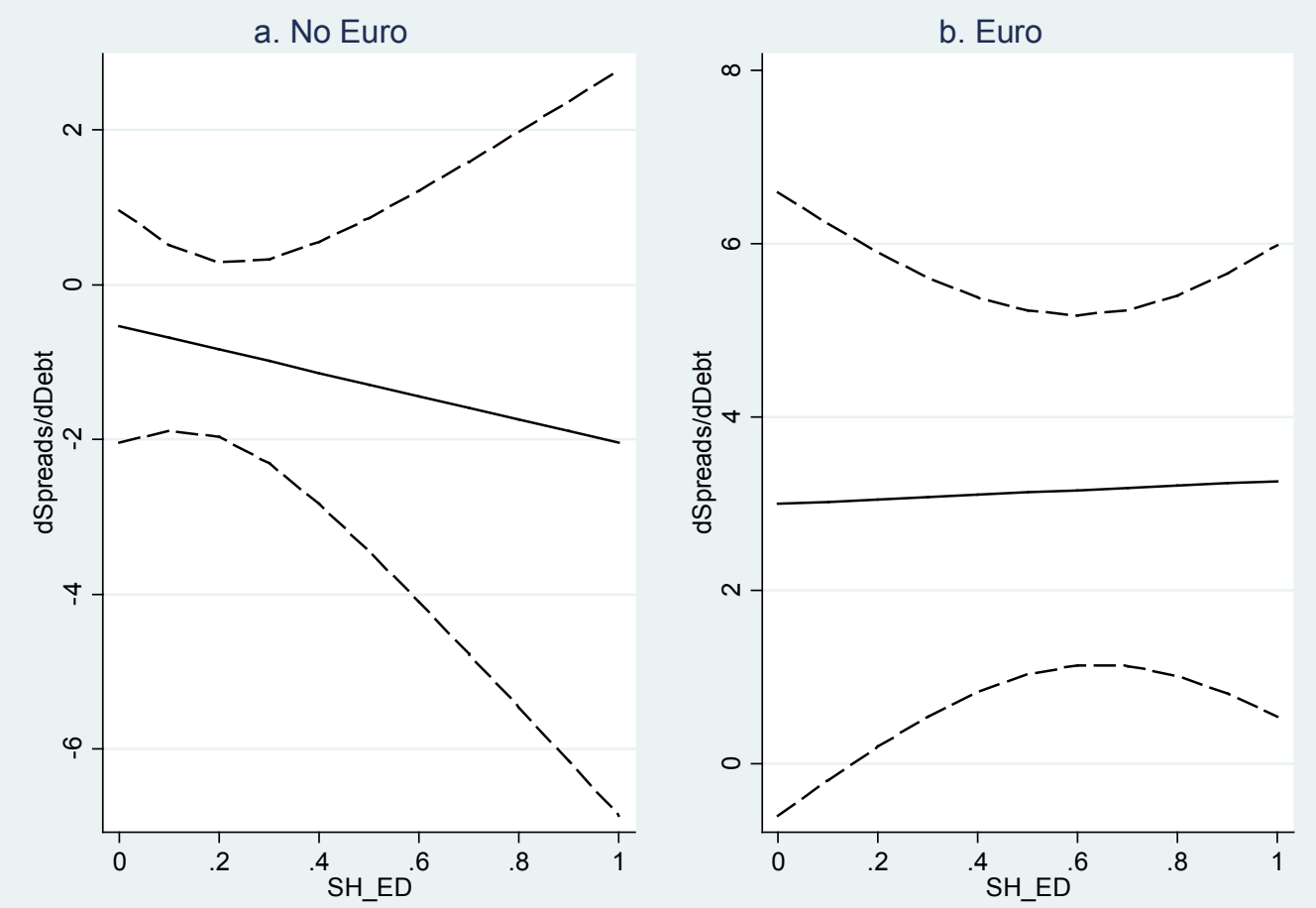

This figure shows the relationship between sovereign spreads and public debt at different levels of external debt inside and outside the Eurozone. The solid line plots the point estimate and the dashed lines are 95 percent confidence intervals. Both panels are based on column 2 of Table 9. 
Figure 6: Sovereign spreads and public debt at different levels of external wealth in Euro and Non-Euro advanced economies
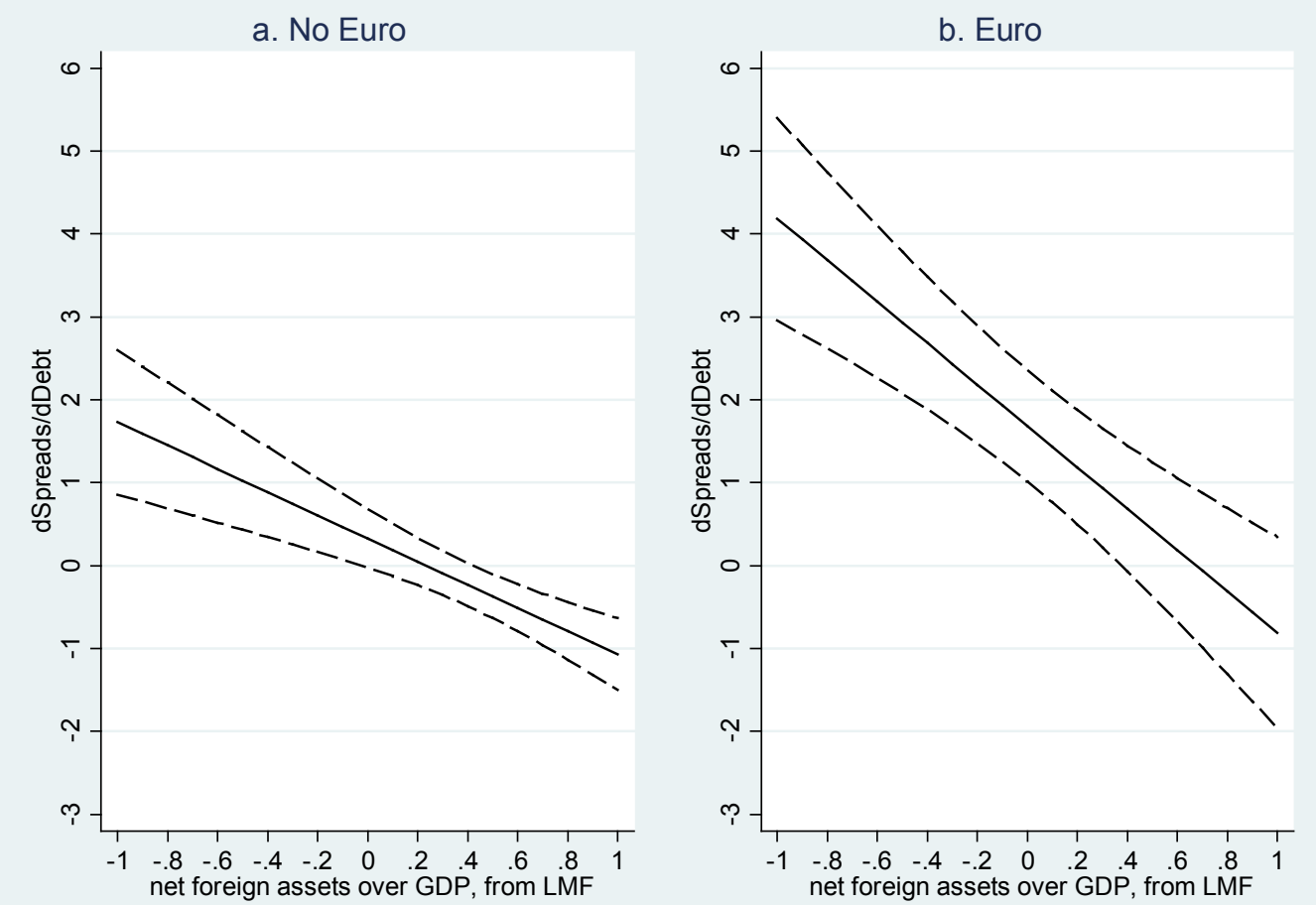

This figure shows the relationship between sovereign spreads and public debt at different levels of net external wealth inside and outside the Eurozone. The solid line plots the point estimate and the dashed lines are 95 percent confidence intervals. Both panels are based on column 4 of Table 9. 
Table A1: Countries included in the sample

\begin{tabular}{|c|c|c|c|c|}
\hline Country & First Observation & Last Observation & Number of periods & Excluded years \\
\hline \multicolumn{5}{|c|}{ Emerging Market Economies } \\
\hline $\mathrm{ARG}$ & 1997 & 2012 & 17 & $2000-05$ \\
\hline BGR & 2000 & 2012 & 24 & \\
\hline BRA & 2000 & 2012 & 24 & \\
\hline $\mathrm{CHL}$ & 1999 & 2012 & 27 & \\
\hline $\mathrm{CHN}$ & 1994 & 2012 & 36 & \\
\hline $\mathrm{COL}$ & 1997 & 2012 & 31 & \\
\hline DOM & 2001 & 2012 & 22 & \\
\hline ECU & 2003 & 2012 & 11 & $1998-2002 ; 2008-10$ \\
\hline EGY & 2002 & 2012 & 20 & \\
\hline HUN & 1999 & 2012 & 27 & \\
\hline IDN & 2004 & 2012 & 16 & \\
\hline KAZ & 2007 & 2012 & 10 & \\
\hline MEX & 1996 & 2012 & 32 & \\
\hline MYS & 1996 & 2012 & 32 & \\
\hline PAK & 2002 & 2012 & 20 & $1997-2002$ \\
\hline PAN & 1996 & 2012 & 32 & \\
\hline PER & 2000 & 2012 & 24 & \\
\hline PHL & 1998 & 2012 & 29 & \\
\hline POL & 1995 & 2012 & 34 & \\
\hline RUS & 2001 & 2012 & 22 & $1998-2000$ \\
\hline SLV & 2002 & 2012 & 21 & \\
\hline TUN & 2002 & 2012 & 21 & \\
\hline TUR & 2000 & 2012 & 24 & \\
\hline URY & 2001 & 2012 & 11 & $2003-05$ \\
\hline VEN & 1994 & 2012 & 36 & \\
\hline ZAF & 2000 & 2012 & 24 & \\
\hline \multicolumn{5}{|c|}{ Advanced Economies } \\
\hline AUS & 1994 & 2012 & 36 & \\
\hline AUT & 1995 & 2012 & 35 & \\
\hline BEL & 1993 & 2012 & 38 & \\
\hline $\mathrm{CAN}$ & 1993 & 2012 & 38 & \\
\hline DNK & 1993 & 2012 & 38 & \\
\hline ESP & 1993 & 2012 & 38 & \\
\hline FIN & 1996 & 2012 & 33 & \\
\hline FRA & 1993 & 2012 & 38 & \\
\hline GBR & 1993 & 2012 & 38 & \\
\hline GRC* & 2003 & 2012 & 18 & \\
\hline IRL & 2002 & 2012 & 20 & \\
\hline ITA & 1993 & 2012 & 38 & \\
\hline JPN & 1993 & 2012 & 38 & \\
\hline NLD & 1993 & 2012 & 38 & \\
\hline PRT* & 1995 & 2012 & 35 & \\
\hline SWE & 1993 & 2012 & 38 & \\
\hline
\end{tabular}

*Greece and Portugal are not included in the benchmark regressions 
Table A2: Correlation between the index of fundamentals and its components

\begin{tabular}{|l|c|c|c|c|c|c|c|c|c|c|}
\hline & \multicolumn{5}{|c|}{ Emerging Market Economies } & \multicolumn{5}{c|}{ Advanced Economies } \\
\hline & FUND & DEBT2Y & DEBT2R & BUD_DEF & CA_DEF & FUND & DEBT2Y & DEBT2R & BUD_DEF & CA_DEF \\
\hline FUND & 1 & & & & & 1. & & & & \\
\hline & & & & & & & & & & \\
\hline DEBT2Y & 0.69 & 1 & & & & 0.42 & 1 & & & \\
\hline p-value & 0.00 & & & & & 0.00 & & & & \\
\hline DEBT2R & 0.51 & 0.77 & 1 & & & 0.56 & 0.93 & 1 & & \\
\hline p-value & 0.00 & 0.00 & & & & 0.00 & 0.00 & & & \\
\hline BDGT_DEF & -0.18 & -0.07 & -0.04 & 1 & & 0.92 & 0.34 & 0.44 & 1 & \\
\hline p-value & 0.00 & 0.05 & 0.39 & & & 0.00 & 0.00 & 0.00 & & \\
\hline CA_DEF & 0.78 & 0.10 & 0.01 & -0.03 & 1 & 0.53 & -0.25 & 0.08 & 0.24 & 1 \\
\hline p-value & 0.00 & 0.01 & 0.92 & 0.42 & & 0.00 & 0.30 & 0.05 & 0.00 & \\
\hline
\end{tabular}

